University of Nebraska - Lincoln

DigitalCommons@University of Nebraska - Lincoln

1990

\title{
Sedimentary paleoenvironments of fossil platyrrhine localities, Miocene Pinturas Formation, Santa Cruz Province, Argentina
}

Thomas Bown

U.S. Geological Survey

Claudio N. Larriestra

Universidad Nacional de la Patagonia "San Juan Bosco"

Follow this and additional works at: https://digitalcommons.unl.edu/usgsstaffpub

Part of the Earth Sciences Commons

Bown, Thomas and Larriestra, Claudio N., "Sedimentary paleoenvironments of fossil platyrrhine localities, Miocene Pinturas Formation, Santa Cruz Province, Argentina" (1990). USGS Staff -- Published Research. 243.

https://digitalcommons.unl.edu/usgsstaffpub/243

This Article is brought to you for free and open access by the US Geological Survey at DigitalCommons@University of Nebraska - Lincoln. It has been accepted for inclusion in USGS Staff -- Published Research by an authorized administrator of DigitalCommons@University of Nebraska - Lincoln. 
Thomas M. Bown

[S. Geological Surey, Denier. C. lorado, 80225, LS.A.

\section{Claudio N. Larriestra}

L iversidad Nacional de la

F.tagonia "San Juan Bosco", 9000

C.modoro Rizadaita (Chubut

$P$ mince), Argentina

R ceived 10 March 1989

R rision received 20 April 1989

and accepted 21 April 1989

Kitords: Pinturas Formation,

Niocene, paleosols, holostrome

ronstruction, platyrrhine

p:inates.

\section{Sedimentary paleoenvironments of fossil platyrrhine localities, Miocene Pinturas Formation, Santa Cruz Province, Argentina}

The Pinturas Formation is a pyroclastic and epiclastic aeolian deposit of Miocene age lying discordantly upon Jurassic rocks in the elevated Andean precordillera of northwest Santa Cruz Province, Argentina. The history of development of the Pinturas Formation was significantly affected by the gradual. though sporadic. draping of this aeolian sediment across a profound, slowly filling paleotopography. The Pinturas depositional cycle consisted of: (1) minor aeolian deposition followed by soil formation, and (2) major aeolian deposition followed by intervals of regional erosion. Fluvial action seems to have been almost wholly confined to intraformational erosion, and two significant intraformational erosional unconformities divide the Pinturas Formation into three sequences. The lower sequence is dominated by prroclastic mudrocks upon which were formed very mature, probably mollic, paleosols; the middle sequence is composed largely of epiclastic sand occurring as barchanoid paleodunes; and the upper sequence consists of massive, poorly bedded pyroclastic mudrocks. Many Pinturas lacunae were reconstructed on the basis of locally preserved strata, and a novel method of holostrome reconstruction using relative paleosol maturities places Pinturas sedimentation in a more accurate temporal light. It also indicates: (1) that the Pinturas sediment accumulation rate increased with time; (2) that regional erosive intervals are correlated directly with major influxes of pyroclastic material; and (3) that the introduction of the Pinturas platyrrhine primates occurred in the sequence: Carlocebus carmenensis, C. intermedius and Soriacebus ameghinorum, Soriacebus adrianae.

Pinturas paleosols appear to have formed under moist conditions, and both mature and immature varieties vield a host of ichnofossils. These include the burrows and nests of bees, scarabeid beetles, termites, and at least two different kinds of colonial rodents, in addition to rhizoliths and the calcified boles and root systems of trees. A fossil nest of a nasutitermitine termite in the lower sequence of the formation indicates the presence of tropical forest. Climatic conditions may have been drier during deposition of the barchanoid paleodunes in early late Pinturas time, or the dunes might reflect drier source areas or have simply encroached on areas of highland forest. Fossil mammals are abundant in Pinturas sediments, and attritional concentrations of them were recognized in the upper parts of paleosols and on the floors of erosional scours. Radiometric dates indicate that the fossil mammals (including platyrrhine primates) occurring in the lower and middle parts of the formation may range in age from about $16 \cdot 6$ to younger than 13.3 Ma (million vears ago) (Santacrucian and, almost certainly; Friasian land-mammal ages). This age range is somewhat younger than previous estimates, and suggests that the Pinturas faunas correlate broadly with those from the type Santa Cruz Formation, with the presumed position of the type Friasian, and with the base of the marine Gaiman Formation in the lower valley of the Río Chubut.

Journal of Human Eiolution (1990) 19, 87-119

\section{Introduction}

\section{Location}

The name Pinturas Formation was applied by Bown et al. (1988a) to up to $100 \mathrm{~m}$ of Miocene continental pyroclastic and eolian epiclastic sediments distributed in the upper valley of the Río Pinturas and its tributaries, northwest Santa Cruz Province, Argentina (Figure 1). This area is in the eastern part of the elevated Andean precordillera of western 


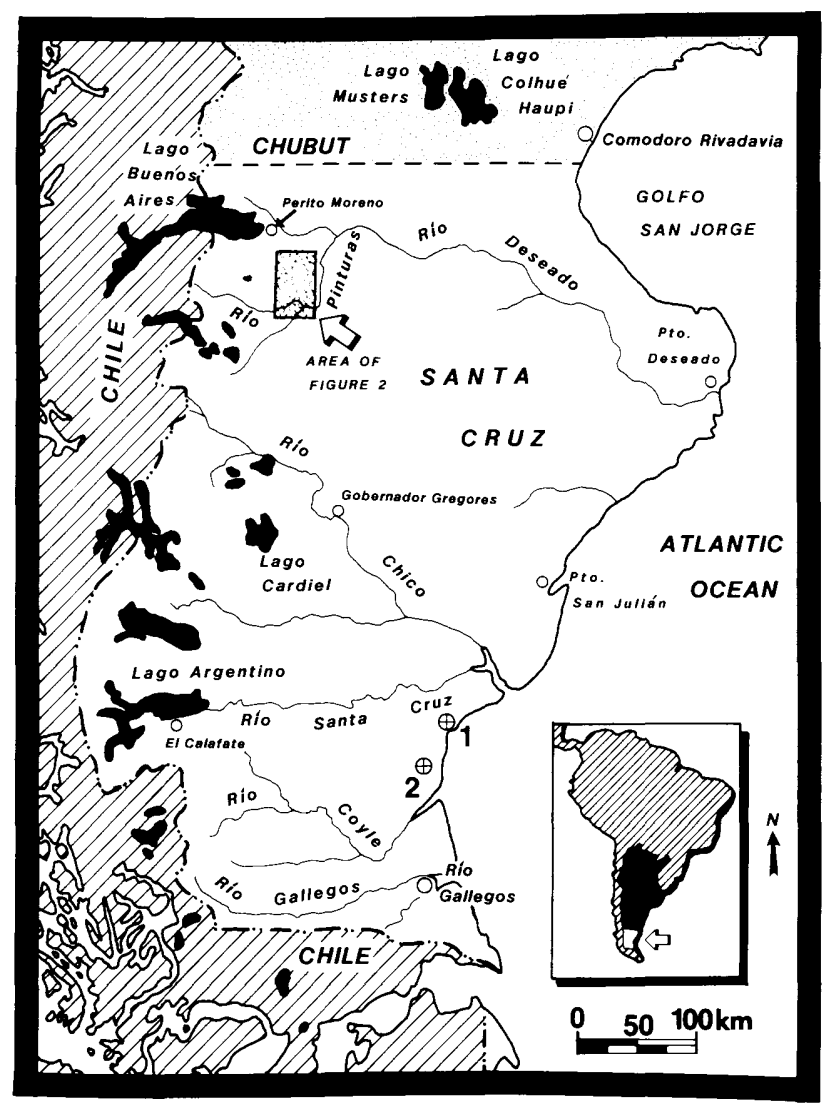

Figure 1. Map of Santa Cruz Province, Argentina, showing location of study area in the valley of the Rio Pinturas (inset), with respect to other locations discussed in the text. Localities: $1=$ Monte León; $2=$ Monte Observacion.

Patagonia, at the eastern border of the Deseado Massif (de Barrio et al., 1984). The type and most complete section of the Pinturas Formation is at Estancia Ana Maria (Figure 2), about $55 \mathrm{~km}$ south of the town of Perito Moreno (47 $1^{\prime} 44^{\prime \prime}$ South Latitude. $70^{\circ} 44^{\prime} 50^{\prime \prime}$ West Longitude), where it is spectacularly exposed in extensive badlands (Figures 3, 4, 5C). Exposures are also excellent in Arroyo Feo (Figure 5B), a few kilometers north of the type section, and good, but small and patchy outcrops occur on the flanks of Meseta Sumich and, farther north, in Arroyo La Caldera and Arroyo Telken. South of the type section, exposure is limited to a few small areas in the valley of the Río Ecker, in Cañadon Caracoles and Cañadon Seco, in Cañadon Olvidado, at Estancia El Carmen (Figure 5A), and in the vicinity of Cerro Chato (Figure 2).

\section{Characterization and distribution}

The Pinturas Formation is distinguished from Ameghino's (1889) Santa Cruz Formation (to which it was referred by all earlier authors) in: (1) its much greater volume of primary (unrecycled) pyroclastic sediment; (2) the paucity of alluvial rocks; (3) the absence of marine intercalations; (4) the presence of two major intraformational unconformities, and 


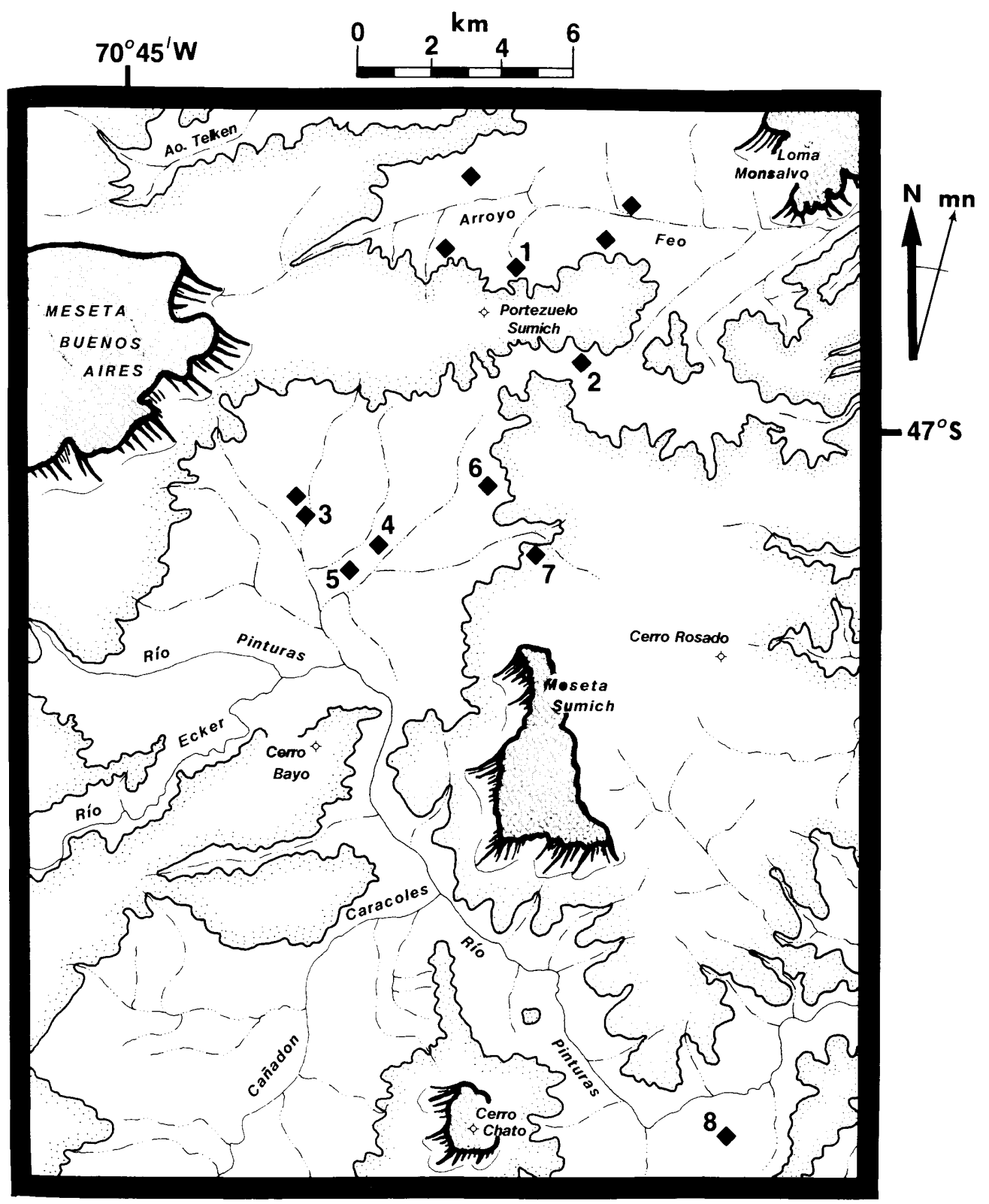

Figure 2. Map of the middle valley of the Río Pinturas, about $50 \mathrm{~km}$ south of the town of Perito Moreno, santa Gruz Province, depicting locations of some of the major fossil vertebrate sites discussed in the text. 1 = Portezuelo Sumich Norte: 2 = Portezuelo Sumich Sur; 3 = Estancia Ana Maria (Loma de las Ranas) $; 4=$ Loma de la Lluvia; $5=$ Cerro de los Monos; 6 = Estancia Los Toldos Norte; $\bar{\imath}=$ Estancia Los Toldos Sur; $8=$ Estancia El Carmen. Contour at $700 \mathrm{~m}$ is depicted and immediate higher elevations mphasized by stippling. 

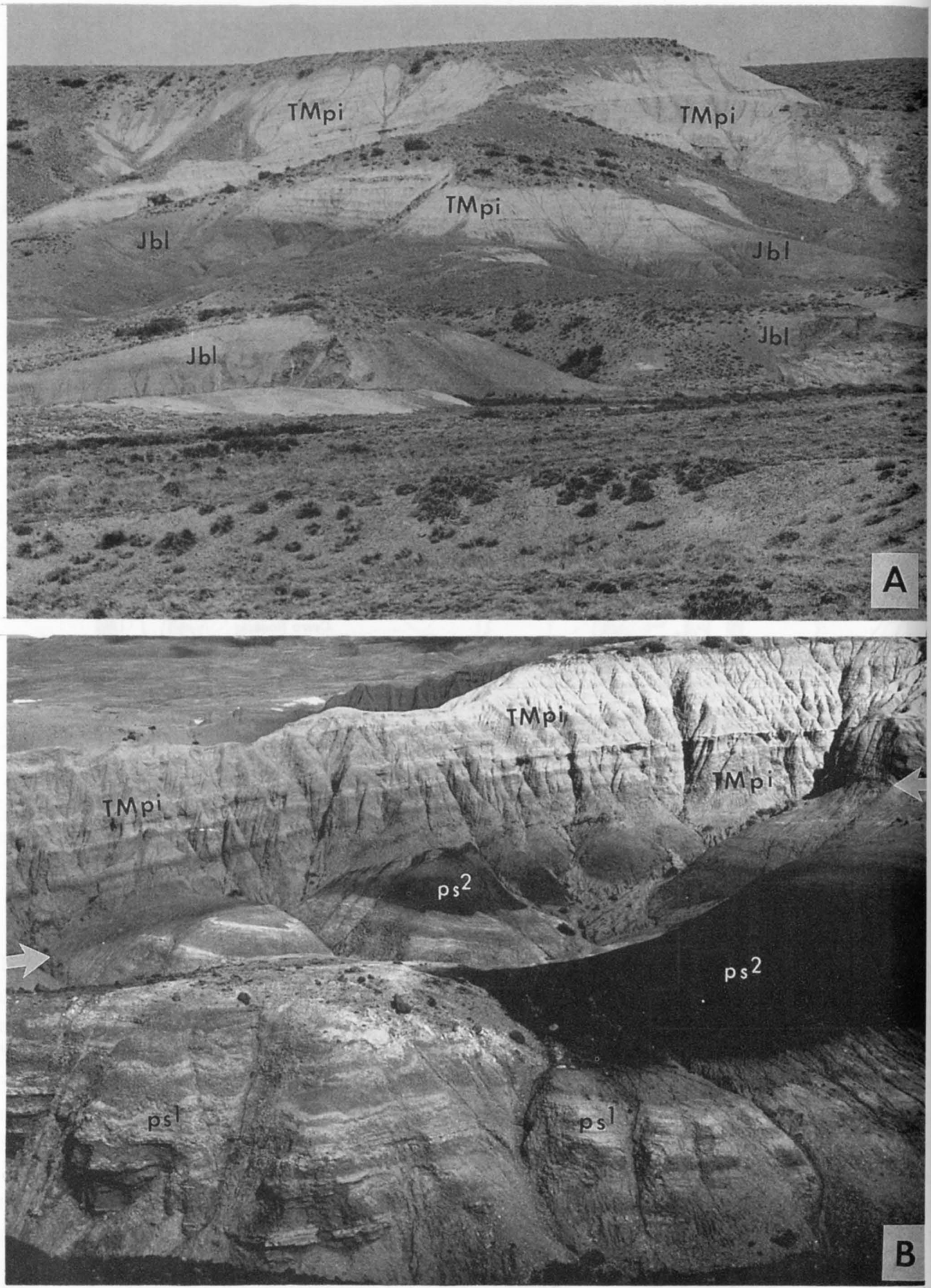

Figure 3. Topographic relations of Miocene Pinturas Formation to underlying Jurassic rocks of the Bahía Laura Group (A), and younger rocks (B). A: tilted, pedogenically modified light-colored Pinturas pyroclastic rocks (TMpi) overlying flat-lying red sandstones and mudrocks of Bahía Laura Group (Jbl) with erosional unconformity, south of Portezuelo Sumich. Note how depositional dip of Pinturas strata conforms with dip of surface of erosion on Bahía Laura rocks. B: tilted, pedogenically modified Pinturas pyroclastics (TMpi) overlying tilted post-Bahía Laura and pre-Pinturas pedogenically modified colluvial (ps1) and volcaniclastic (ps2) rocks with angular unconformity at Estancia Ana Maria. Unconformity marked by arrows. Note how Pinturas strata do not abut the truncated older strata, rather they dip like the surface of erosion, off the erosional high in the upper part of the center of the photograph, and into the valley beyond at the upper left. 
(5. the significantly greater volume of pedogenically-modified sediment representing very miture paleosols. Poorly-exposed Tertiary pyroclastic rocks resembling parts of the Pinturas Formation at its type locality occur $140 \mathrm{~km}$ farther south near Las Horquetas, and roks vielding Santacrucian mammals near Gobernador Gregores (Figure 1), as well as un prospected Miocene rocks near Lago Cardiel (Ramos, 1982), resemble sections of the Pinturas Formation more than they do those of the typical coastal Santa Cruz Formation (e y., at Monte León and Monte Observacion; Figure 1).

Pi:ious work

Vertebrate fossils were first collected in the Pinturas River valley by Carlos Ameghino in 1891. In 1900-02, his brother Florentino Ameghino referred the fossil-bearing rocks to his (1889) "formación Santacruceaña", but (1906) opined that the mammals (forming part of hi " Astrapothericulense fauna") were older than those of his typical "Santacruzienne" (Santacrucian) fauna. Correspondingly, and based on a new collection made by him, Frenguelli (1931) believed that the Pinturas mammal fauna contained elements of what are now regarded to be both Colhuéhuapian and Santacrucian faunas. This led Castellanos (1937) to coin the term "Pinturense" for a new mammal age he inferred to be typified by the Pinturas mammals.

Pascual et al. (1965) and Pascual \& Odreman Rivas (1971) referred Ameghino's "Astrapothericulense fauna" (including the Pinturas mammals) to a "Santacrucense" age. This view essentially echoed that of Wood \& Patterson (1959) and was accepted later by Marshall (1976); namely, that the Pinturas mammals are not older than Santacrucian age, but exactly where within that age they belong could not be determined. An early Suntacrucian age was suggested by Marshall et al. (1977) and reiterated by Marshall et al. (1983). This would indicate an age of about $18 \cdot 0-16 \cdot 5 \mathrm{Ma}$ (million years ago) for the Pinturas mammals, using the geochronology for the type Santacrucian offered by Marshall ef al. (1986) - an age appreciably younger than estimates for the base of the Santacrucian offered by earlier authors (e.g., Savage \& Russell, 1983). Fossil vertebrates were also collected from the Pinturas Formation by Di Persia (1959), and de Barrio et al. (1984). The latter authors believed the Pinturas sediments to be characteristic of deposition on distal alluvial floodplains ("llanuras aluviales distales"), the mammals from them suggesting an early Miocene age.

From 1985-1989, an ongoing joint paleontological expedition of the Museo Argentino de Ciencias Naturales (Buenos Aires) and the State University of New York (Stony Brook) has been exploring the Miocene deposits of the Río Pinturas valley to enhance the fossil record of the platyrrhine primates of Argentina, and to place the Pinturas fauna in its geologic and paleoenvironmental context. Fleagle (1990) and Fleagle et al. (1987) described the first fossil primates from those rocks. Bown et al. (1988a) gave formation-rank status (Pinturas Formation) to all Miocene continental pyroclastic rocks in the Pinturas River valley and adjoining areas, and recognized the first significant paleodune sands in the Argentine Miocene. These deposits have now also been provisionally identified in the type and adjoining areas of the coastal Santa Cruz Formation (Larriestra et al., in press), and have significant implications for Santacrucian depositional paleoenvironments and correlation as well as for the habitats of Pinturas and Santa Cruz platyrrhine primates.

Bown et al. (1988b) determined a radiometric age of $16 \cdot 6 \pm 1 \cdot 5 \mathrm{Ma}$ for rocks near the base of the Pinturas Formation. This age suggests that, in general, the Pinturas faunas may be of more similar age to faunas of the type Santa Cruz Formation than previously believed. 

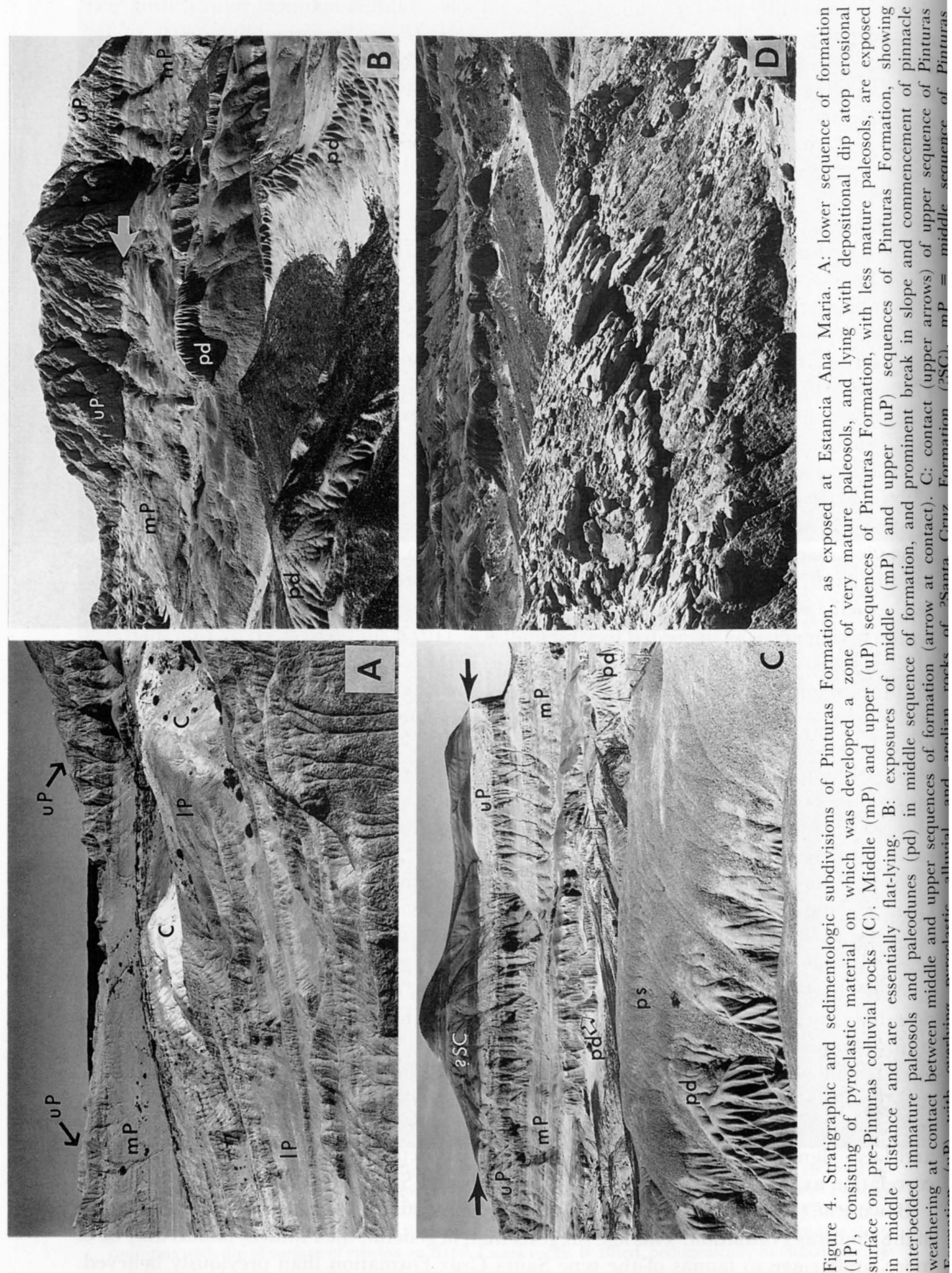

嗐

$\exists \widetilde{\Xi} \Xi$

E 응 $\widetilde{g}$

है

o

릉 듈 吾

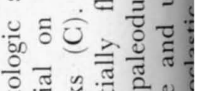

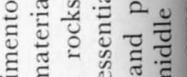

次

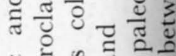

跣记

$\because$ on 0 i

+

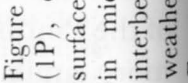




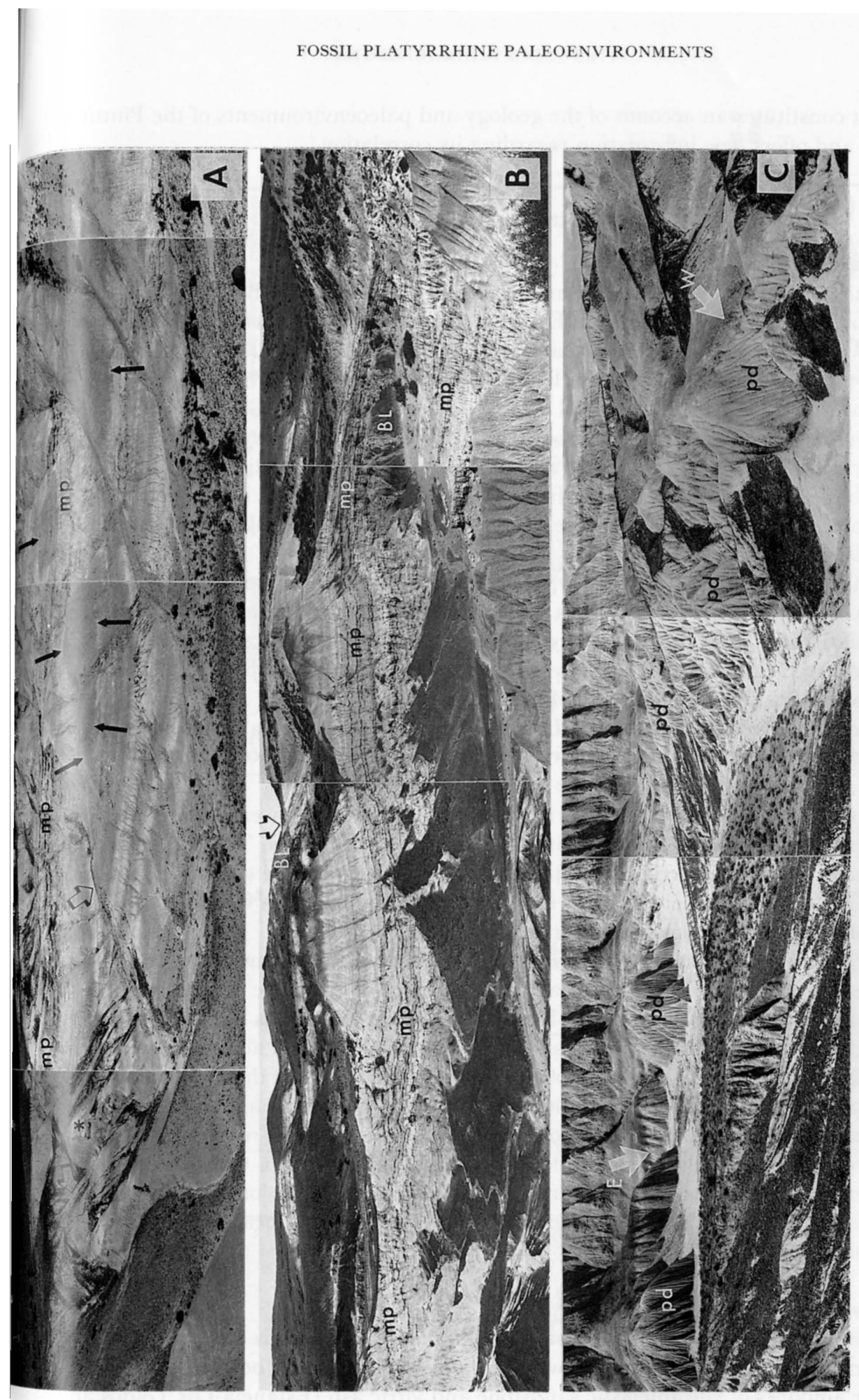

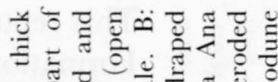

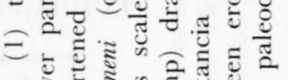

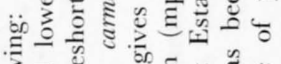

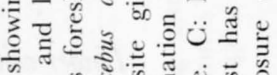

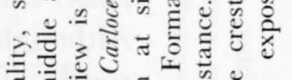

可地

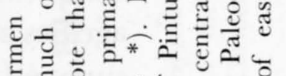

đु

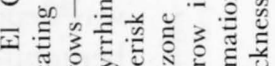

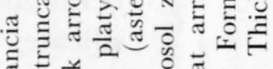

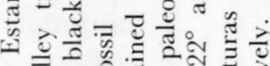

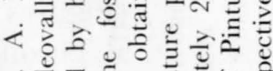

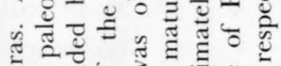

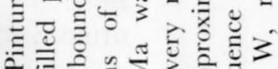

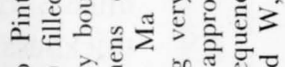

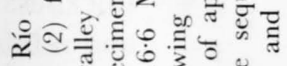

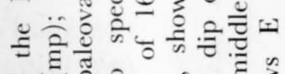

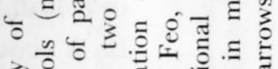

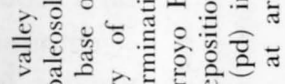

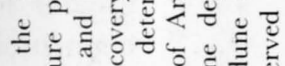

E

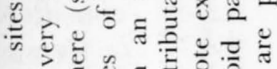

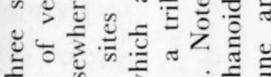

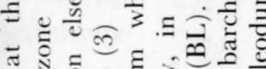

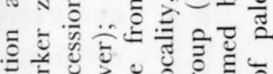

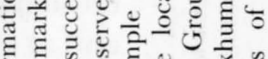

เั

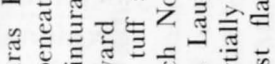

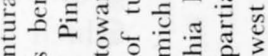

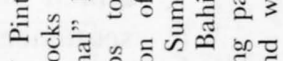

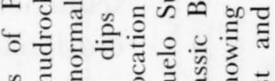

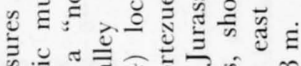

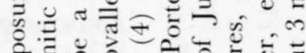

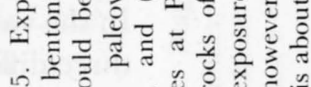

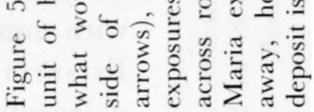


This report constitutes an account of the geology and paleoenvironments of the Pinturas Formation and offers new information regarding its correlation.

\section{Stratigraphy}

\section{Lower contact}

Although the Pinturas Formation lies unconformably atop Jurassic Bahía Laura Group rocks in most areas (Figures $3 \mathrm{~A}, 5 \mathrm{~B}$ ), at Estancia Ana Maria the contact relations are more complex. There, up to about $30 \mathrm{~m}$ of coarse, white to pinkish colluvial debris of unknown age lies atop the Bahía Laura (Figures 3B, 4A). This unit is succeeded by a profound scour surface (up to $50 \mathrm{~m}$, cutting locally well down into the Bahía Laura Group), upon which was deposited up to $10 \mathrm{~m}$ of reddish-brown to golden volcanic sandstone and variegated, bentonite-rich volcaniclastic mudrocks rich in glaebules of diagenetic cryptocrystalline silicate. These units overlie rocks of the Bahía Laura Group with either erosional or angular unconformity, and underlie the Pinturas Formation with angular unconformity (Figures 3B, 4A).

Throughout the Río Pinturas valley, a very mature post-Jurassic and pre-Miocene paleosol is developed on Bahía Laura rocks, just under the surface of the systemic unconformity, and conforming well to its paleotopography. This paleosol has a B horizon thickness of up to $9 \mathrm{~m}$, and appears to have formed indiscriminately on Bahía Laura basalts and mudrocks alike. At Estancia Ana Maria, immature paleosols are seen in the ancient colluvial debris derived from the Bahía Laura Group, more mature paleosols occur in the overlying volcaniclastic sediments (Figure 3B), and the base of the Pinturas Formation lies on a scour surface truncating one or the other of these units.

An unusual feature of the Pinturas Formation is that rocks in its lower part are tilted at a greater inclination than are those in its middle and upper parts. This aspect of the depositional dip of the light-colored Pinturas strata, coupled with the various inclinations of the highly deformed, generally brick red rocks of the Bahía Laura Group, emphasizes considerably their unconformable relations.

Extensive intraformational erosion has removed much of the Pinturas section in most areas. The type section at Estancia Ana Maria is the most complete and most outlying sections can be readily correlated to it (Figure 6). The type section is divisible into three successive units, here termed sequences, each of which is bounded above and below by erosional unconformities. The amount of section removed at each of these unconformities and at other, lesser, unconformities in the various sections is variable and appears to have been related to the topographic position of the Pinturas sediment with respect to that of the erosional contact with rocks of the underlying Bahía Laura Group. Consequently, just which lithologies constitute the basal, middle, or uppermost units of each of the three sequences of the Pinturas Formation in local exposures is a result of local post-depositional erosional histories.

\section{Lower sequence}

In the valley of the Río Pinturas, the base of the Pinturas Formation is composed of one of three different rock types: (1) pink, brown, green, and yellow sandy bentonitic mudrocks with minor amounts of volcaniclastic sandstone and vitric ash (Estancia Los Toldos and Estancia El Carmen; Figures 5A, 6); (2) a series of highly bioturbated very mature paleosols developed on sandy volcaniclastic mudrocks (Portezuelo Sumich Norte and 


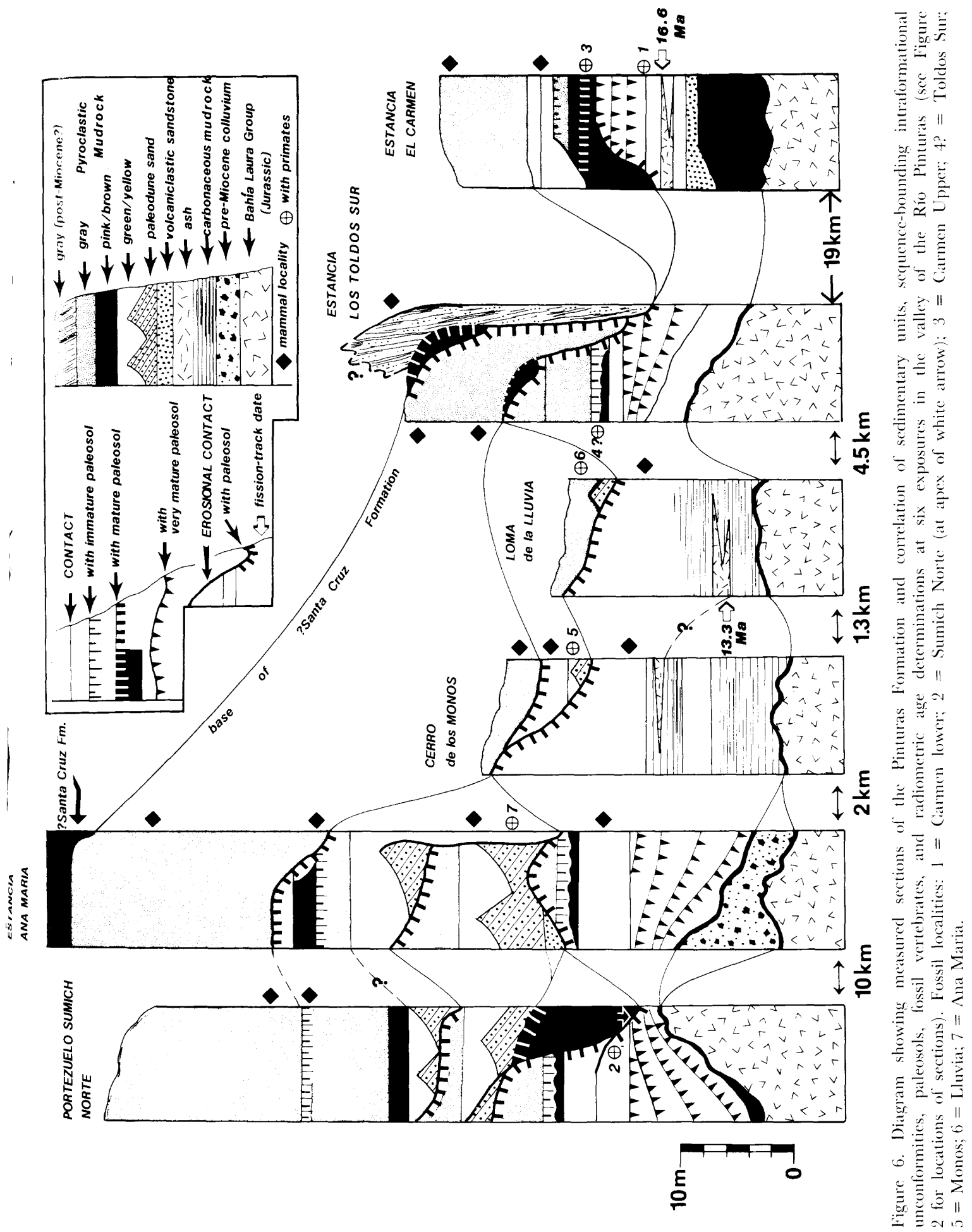


Estancia Ana Maria; Figures 3B, 4A, 5B, 6); or (3) a sequence of carbonaceous volcaniclastic shale and sandy mudrock interbedded with vitric ash [Cerro de los Monos and Loma de la Lluvia (Figure 6) and, locally, in Arroyo Feo].

Nearly every unit in every section of the Pinturas Formation was altered somewhat by penecontemporaneous Miocene pedogenesis. Some of these paleosols obviously required more time to form than others, and a zone of superposed, exceptionally mature paleosols in the lower sequence of the Pinturas Formation is so thick and lithologically distinctive that it is a useful stratigraphic marker. This zone is developed at the bases of the sections at Portezuelo Sumich Norte and Estancia Ana Maria, it occurs a few meters above the section base at Estancia Los Toldos, and is found in the middle of the section at Estancia El Carmen (Figures 3B, 4A, 5A and B, 6). Because this group of exceptionally mature paleosols is invariably restricted to the lower sequence of the Pinturas Formation, it is inferred to represent more or less isochronous periods of intense Miocene soil formation throughout the Pinturas River valley and, with the two intraformational unconformities bounding the middle sequence of the formation, constitutes our basis for regional intraformational correlation. The paleosols in this zone, as in the Pinturas Formation in general, invariably formed upon primary pyroclastic parent materials. They generally possess a dark gray organic epipedon and rhizolith-rich zones in the A horizon. The $\mathrm{B}$ horizons commonly have zones well cemented with $\mathrm{CaCO}_{3}$, and others which show evidence of modest clay illuviation. Both the $\mathrm{A}$ and $\mathrm{B}$ horizons are intensely bioturbated.

At Cerro de los Monos and Loma de la Lluvia (Figure 6), the very mature paleosol zone is absent and the base of the formation is made up of carbonaceous shales and mudrocks. These units are also largely pyroclastic, they contain abundant nodular and granular jarosite and lepidocrocite and crystals of selenite, and are rich in plant remains and detrital organic debris. They generally have one to three $10-20 \mathrm{~cm}$ thick interbeds of white vitric volcanic ash. In Arroyo Feo, calcareous concretions yielding poorly-preserved fish remains were encountered in the carbonaceous shales. Stratigraphic relations in the western exposures at Estancia Ana Maria and in southern tributaries of Arroyo Feo indicate that these carbonaceous shales and mudrocks correlate with the upper part of the very mature paleosol zone.

In the type section, at Portezuelo Sumich Norte, and at Estancia Los Toldos Sur, the very mature paleosol zone is capped by up to $12 \mathrm{~m}$ of sandy yellow, green, or pink bentonitic mudrock containing relatively immature paleosols. These soils commonly contain areas of grouped black (manganiferous) or white (calcareous) burrows, formed by several generations of colonial rodents. At Cerro de los Monos and Loma de la Lluvia (Figure 6), where the very mature paleosol zone is absent, the correlative interbedded carbonaceous shales and mudrocks are overlain by thick deposits of sandy green and yellow volcanic mudrock. At Estancia El Carmen, the very mature paleosol zone forms the top of the lower sequence of the Pinturas Formation, and is truncated by a deep scour; a relation also seen locally at Portezuelo Sumich Norte (Figure 6).

\section{Middle sequence}

The base of the middle sequence of the Pinturas Formation was deposited on a regional scour surface; thus additional, though unrepresented, lower sequence deposition took place prior to initial deposition of the middle sequence. A mature, organic-rich paleosol (mollisol?) was developed regionally on this scour surface. In most sections, the geometry 

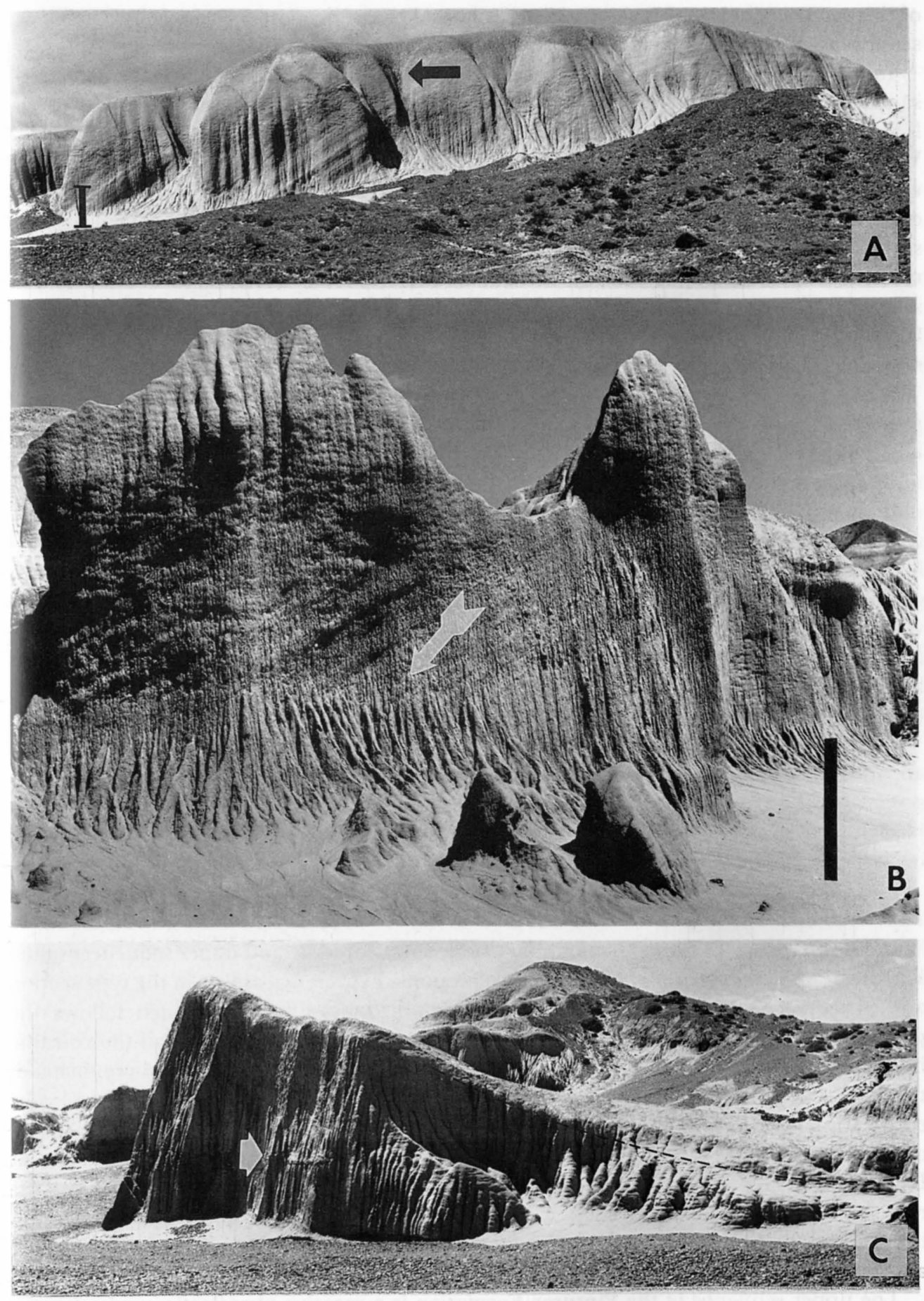

Figure 7. Paleodune deposits in the middle sequence of the Pinturas Formation, Estancia Ana Maria. A: natural cross-section of barchanoid paleodune, showing cross-stratification of paleodune foresets. Arrow shows direction of paleowind, bar is $2.0 \mathrm{~m}$. B: natural cross-section of barchanoid paleodune, showing paleodune foresets and phreatic zone boundary (arrow) of relatively uncemented and relatively well-cemented paleodune sand. Bar is $1.0 \mathrm{~m}$. C: exhumed flank of barchanoid paleodune, showing steep descent of paleodune wings (emphasized at lower right) and phreatic zone contact (arrow). Azimuth of paleowind flow was directly into the picture. Height of eroded paleodune face at left is $5.3 \mathrm{~m}$. 
of this scour is obvious. However, in areas lateral to the deepest scouring, the level of the scour is represented solely by the thick organic-rich paleosol.

In the type section and at Portezuelo Sumich Norte, two deposits of epiclastic paleodune sandstone with associated interdune pyroclastic mudrock lie in the scour separating the lower and middle sequences of the Pinturas Formation (Figures $4 \mathrm{~B}$ and $\mathrm{C}, 5 \mathrm{C}, 6$, and 7). Where two paleodune deposits are present, they are separated by a surface of erosional unconformity. Only one deposit of paleodune sand exists at Cerro de los Monos and Loma de la Lluvia, and it is uncertain which, if either, of the two paleodune deposits in the type section these represent. Most of the entire middle sequence of the Pinturas Formation is missing at Estancia Los Toldos Norte, and at Estancia El Carmen (Figure 6) the middle sequence, though present, contains no paleodune sands. A solitary, thin, volcaniclastic fluvial channel sandstone (Figure 4D) occurs locally at the base of the middle Pinturas sequence at Estancia Ana Maria.

Where best developed, the paleodune sandstones and interbedded and interdune pyroclastic mudrocks attain a thickness of about $30 \mathrm{~m}$; the thickest individual dune deposit being about $12 \mathrm{~m}$. The sand is uniformly medium-fine, and frosted grains, though by no means abundant, are most common in the upper parts of the individual deposits. The upper parts of the paleodune sands are also friable, whereas the lower one or two meters are generally weakly cemented with calcium carbonate. The combination of uniform sorting, large-scale unidirectional cross-sets lacking small-scale subsets, and the crescentic geometry of some of these sandbodies identify them as barchanoid paleodunes. A thin volcanic pebble conglomerate occurs associated with interdune deposits at Estancia Ana Maria, but was not seen elsewhere. In most sections, the paleodune sands contain sparse invertebrate burrows as well as larger, grouped burrows, presumably of colonial rodents (Figure 8A).

In the type section, up to $5 \mathrm{~m}$ of green and yellow pyroclastic and bentonitic mudrock lie above each of the paleodune sand deposits and beneath the intraformational unconformity separating the lower and upper sequences of the Pinturas Formation. The lower part of this post-dune deposit is a distinctive and well developed charcoal gray A horizon of a paleosol overlying a few meters of yellow bentonitic mudrock.

\section{Upper sequence}

A major scour surface forms the boundary between the middle and upper sequences of the Pinturas Formation (Figures 4B, 6) in most sections. Especially explicit in the type section and at Cerro de los Monos, this surface is marked by a paleosol which follows the paleotopography of the scour, and formed on the truncated paleodunes and the volcanic mudrocks equally. This scour is not evident at Portezuelo Sumich Norte where, instead, the level of the scour appears to be marked by a relatively immature paleosol (see correlation in Figure 6). The scour is also not well developed at Estancia El Carmen, where only minor scouring and little or no paleosol formation are recorded at this contact. At Estancia Los Toldos Sur, the paleosol is obvious and the scouring profound; the latter is responsible for elimination of most of the middle sequence of the Pinturas Formation in that section, and for having locally cut down to the varicolored bentonitic mudrocks lying above the very mature paleosol zone near the base of the formation.

The upper sequence of the Pinturas Formation is a massive pyroclastic sandstone and sandy mudrock containing numerous, though very immature paleosols. The sequence forms steep, light gray cliffs, locally weathering into distinctive pinnacles (Figures $4 \mathrm{~B}$ and $\mathrm{C}$ ) 

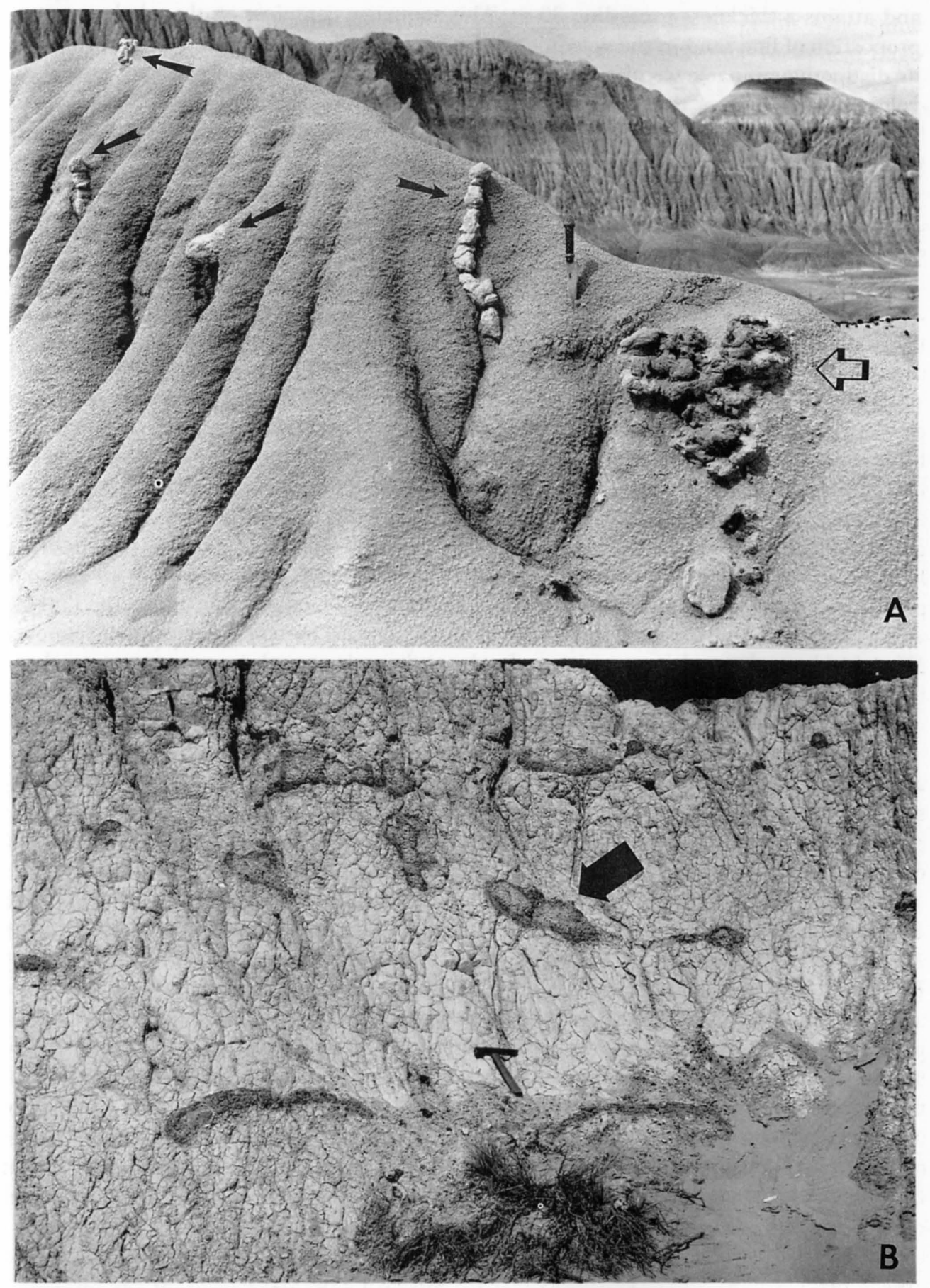

Figure 8. Trace fossils of vertebrates from the Pinturas Formation, Estancia Ana Maria. A: vertical and inclined burrows (black arrows) and nest (open arrow), forming part of a rodent "village" in barchanoid paleodune sands; middle sequence of Pinturas Formation. Knife between large burrow and nest is $18 \mathrm{~cm}$ long. B: nest (arrow) and galleries of an unknown mammal, possibly a dasypodid, in upper sequence of Pinturas Formation. Hammer gives scale. 
and attains a thickness exceeding $30 \mathrm{~m}$. This sequence contains, on the whole, a greater proportion of fine sand in the volcanic mudrock, an attribute that probably contributes to its distinctive pinnacle weathering. These units also locally contain breccia of intraclastic volcanic mudstone of the same composition as the encasing sediment. Several bands of yellow iron oxyhydrate mineral concentrations are present in the lower $10 \mathrm{~m}$, as are peculiar cylindrical to elliptical zones, stained black with manganese dioxide. Some of these latter structures appear to be burrows (Figure 8B). Calcified roots and stumps of trees are common in this unit, and calcareous concretions yielding fossil mammal remains (at one site, partial dasypodid skeletons) occur locally in it.

\section{Upper contact}

Regionally, the upper contact of the Pinturas Formation with younger rocks is an erosional unconformity; however, this contact is quite variable in different sections. An erosion surface and Quaternary terrace gravels cap the upper sequence of the Pinturas Formation at Portezuelo Sumich Norte, Cerro de los Monos, and Estancia El Carmen. At Loma de la Lluvia, the erosion surface and gravels truncate gray pyroclastics of the middle sequence of the formation. It is only at Estancia Ana Maria and Estancia Los Toldos Sur that good contacts with younger Tertiary rocks are seen.

At Estancia Ana Maria, the Pinturas Formation is overlain by at least $150 \mathrm{~m}$ of light red, violet, dark gray, and chocolate brown bentonitic mudrock, interbedded with gold and brown sandstone. Although this unit lies in shallow scours cut into the top of the Pinturas Formation, the scouring did not penetrate more than a few meters in to the upper sequence. The darkly variegated bentonitic mudrocks and somber sandstones contrast markedly with the underlying light rocks of the Pinturas Formation (Figure 4C). This unit contains more unaltered pyroclastic material than do deposits of the Santa Cruz Formation on the Atlantic coast; nonetheless, it resembles the type Santa Cruz more than do any rocks here ascribed to the Pinturas Formation. Unfortunately, no fossils or vitric tuffs were found in this unit, and its age cannot now be determined.

The relations of the Pinturas Formation to post-Pinturas rocks are more complex at Estancia Los Toldos Sur (Figure 6). At the southern margin of that locality, two well developed scours are found at the top of the formation; the first is about $6-10 \mathrm{~m}$ in depth, and the second (and younger) exceeds $20 \mathrm{~m}$. Pink to dark red bentonitic mudrocks lie in the older scour, and these are complemented locally by thin beds of golden volcanic sandstone. This unit, thin as it is, closely resembles part of the unit overlying the Pinturas Formation at Estancia Ana Maria (?Santa Cruz Formation), and is tentatively referred to it. The rocks filling the younger scour consist of light gray pyroclastic mudrock, locally rich in white calcareous rhizoliths and white dasypodid scutes. The position of this unit with respect to the Pinturas Formation and the inferred ?Santa Cruz beds, as well as the poor, somewhat leached preservation of the scutes, suggest a much younger but unknown age for these rocks. It is the youngest pyroclastic mudrock deposit at Estancia Los Toldos Sur and is not known to occur elsewhere in the Río Pinturas valley.

\section{Sedimentology and paleoclimate}

Introduction

Little detailed sedimentologic or paleoenvironmental work on the Pinturas Formation has been accomplished previously. De Barrio et al. (1984) concluded that most Miocene 
ceposition in the Río Pinturas valley took place on distal alluvial plains-the same (.)nclusion reached earlier by Ramos (1982) for "Santa Cruz" (=Pinturas) rocks near Lago ( ardiel. Bayarsky (1982: 544) observed the significant contribution of pyroclastic debris in the sediment, and Roellig (1982) noted a clay dominance of montmorillonite in Pinturas r. udrocks.

De Barrio et al. (1984:546) also divided the Pinturas Formation into three types of c.rvironmental units, which they termed "subfacies". These units do not correspond stratigraphically to the lower, middle, and upper sequences of the Pinturas Formation, as w. sed here; rather, they were meant to denote changing depositional environments in which cich one was a subenvironment of deposition. These are: (1) "la subfacies de pelitas" mudrocks), (2) "la subfacies de areniscas masivas" (massive sandstones), and (3) "la subfacies 6. areniscas entrecruzados" (cross-bedded sandstones). The mudrock subfacies was believed to te composed of transported particles that were deposited from suspension on an inundated p ain. The carbonaceous beds and fossil tree trunks they believed to indicate humid climates with areas of both forest and prairie. The massive sandstone subfacies was interpreted as crevasse-splays ("depósitos de desbordamiento") deposited on an alluvial plain, and the cross-bedded sandstones as channel fill ("relleno de canal").

The Pinturas Formation is actually a sedimentologically integrated unit that records progressive, though sporadic, acolian fill of a profound and ancient paleotopography. Both the effect of this paleotopography and the physical nature of the successive intervals of acolian sedimentation continued, penecontemporaneously and continuously, to leave their mark on all aspects of the sedimentary and stratigraphic organization of the deposit. Pinturas sediment deposited in water is volumetrically insignificant, and evidence of ..lluvial accumulation is minimal. In fact, it seems that the principal contribution of -reams during Pinturas time was erosion.

Instead of its deposition in water, Pinturas accumulation was characterized almost ciclusively by successive intervals of: (1) pyroclastic (ash fall) or epiclastic (paleodune and) deposition; (2) paleosol development, and (3) erosion. But aeolian deposition and Aluvial erosion contributed far less to the geologic time represented by the Pinturas section than did numerous periods of stability during which Miocene soils (paleosols) were ormed. The morphologies of these paleosols and their relative maturities (relative amounts of time required to form - see Bown \& Kraus, 1987) also reflect the controlling influences of pyroclastic depositional processes and pre-existing topography.

The sedimentary environment of the Pinturas Formation was subject to two different kinds of controls: (1) the allocyclic control of pyroclastic production, corresponding to veneral episodes of Miocene volcanism and, perhaps, related to emplacement of the Fitz Roy Granite (Nullo et al., 1978; Ramos, 1982), or more general Andean volcanism at the iime of formation of the Río Collón Curá ignimbrites (Marshall et al., 1977), and (2) the autocyclic control of the erosional topography developed on the Jurassic Bahía Laura Group. These controls were also instrumental in producing the unusual morphologic character of the Pinturas Formation.

\section{Erosion and paleotopography}

Regionally, the Pinturas Formation lies with erosional or angular unconformity (Figure 3) upon a profound, partially exhumed paleotopography (in excess of $200 \mathrm{~m}$ ) that formed on deformed Jurassic basalts and continental sediments of the Bahía Laura Group. This paleotopography resulted from an episode of post-Bahía Laura and pre-Pinturas structural 

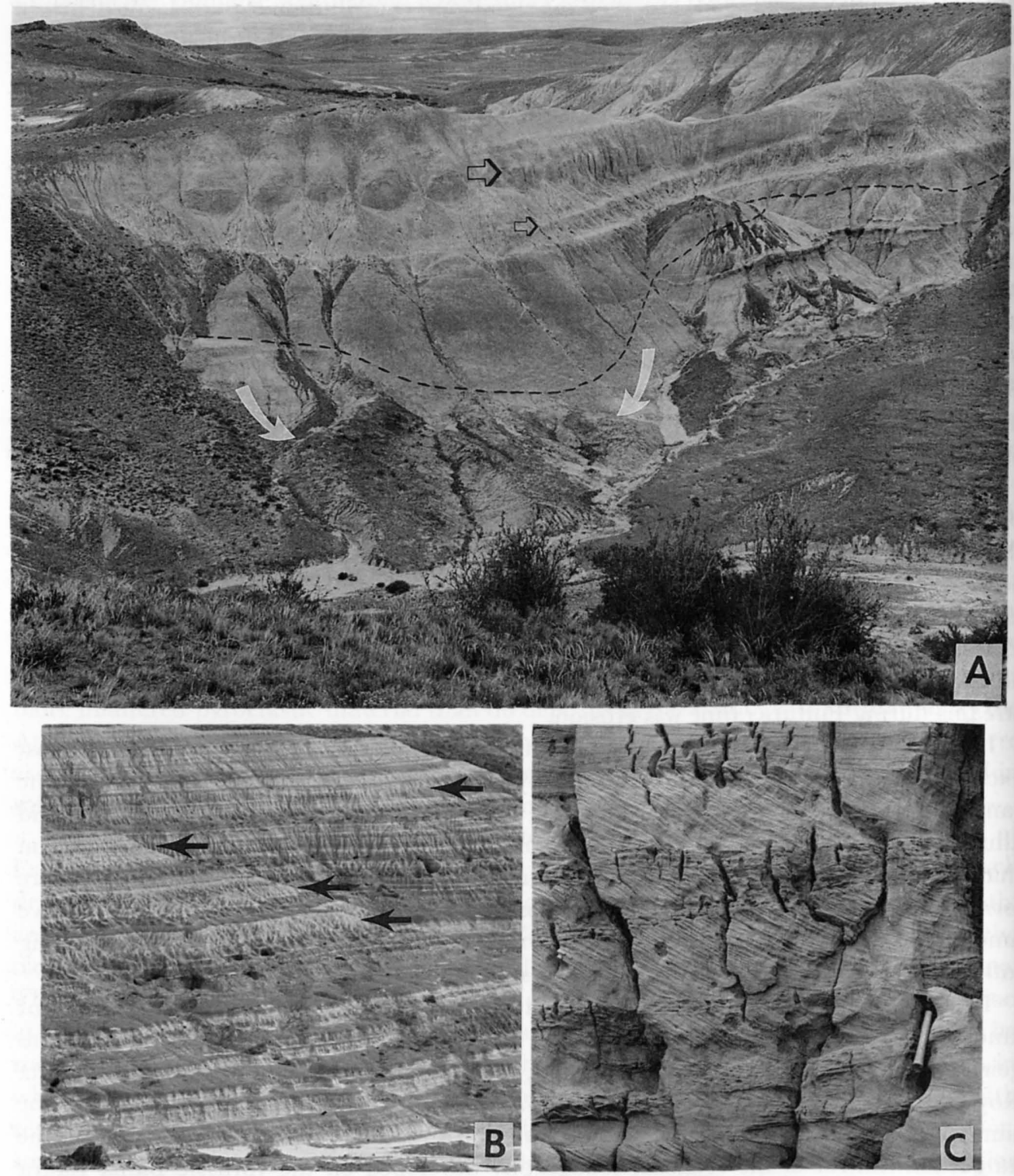

Figure 9. A: fossil primate locality at Portezuelo Sumich Norte. Lag accumulations of fossils occur on the rill fans beneath the filled paleovalley (emphasized), between the white arrows and extending down to the stream bed. The paleovalley is also well exposed on the opposite side of the ridge, and the more extensive rill fan lags there are equally fossiliferous. Note upper (large arrow) and lower (small arrow) paleodune deposits, truncated by minor scour superposed over major paleovalley fill. B: possible paleodunes (arrows) in Santa Cruz Formation at Monte Observacion, southeast Santa Cruz Province (see Figure 1 for location). Ridge about $70 \mathrm{~m}$ high. C: detail of profile, Santa Cruz Formation, Monte Observacion. Hammer gives scale. 
levation of the sedimentary border of the Andean precordillera, and its excision by streams. The distribution of preserved Pinturas rocks suggest that, at one time, Pinturas ind younger rocks completely filled this paleotopography. Because the Pinturas Formation s more readily eroded than are Bahía Laura rocks, the topography developing in the resent erosion cycle is largely recapitulating that which existed immediately prior to Pinturas deposition. The thickest sections of the Pinturas Formation are preserved in the leeper, less eroded parts of the pre-Miocene paleovalleys.

Excavation of this fill by alluvial erosion was also pronounced at many times during Pinturas accumulation. That this was clearly the dominant alluvial effect is attested to by: 1) the overwhelming proportion of fine pyroclastic debris lacking primary sedimentary :tructures characteristic of stream deposits; (2) the presence of numerous channeliform ; cours with lower boundaries marked by paleosols; and (3) the general absence of gravel or ransported sand of fluvial origin on the floors of the scours (de Barrio et al., 1984, record ocal conglomerates in the Pinturas Formation northeast of Las Horquetas). The location is well as the intensity of intraformational erosion was directly controlled by the location of saleovalleys at the contact of the Pinturas Formation and the Bahía Laura Group, and alley profundity. This is determined by the occurrence of several sediment-filled erosional uts superposed on both paleovalleys cut into Jurassic rocks and into sediments filling arlier Pinturas paleovalleys (Figure 6, columns for Estancia Los Toldos, Estancia El Carmen, Estancia Ana Maria, and Portezuelo Sumich Norte; Figure 9, Portezuelo Sumich Vorte). The paleosols that formed on sediments below the floors and sides of these paleovalleys represent the time between the various episodes of paleovalley excavation and renewed sedimentation.

\section{Inclination of Pinturas rocks}

Pinturas rocks are variably inclined (Figures 3, 4A, 5B). Although the inclination might be attributable to tectonics, it is clear that it bears no relation to the structure of the underlying deformed rocks of the Bahía Laura Group. There is also no evidence supporting a refolding of the Bahía Laura. Both the incidence and degree of inclination of Pinturas rocks decreases upward through the local section (e.g., contrast Figure $3 \mathrm{~A}$ with Figures 4B and $\mathrm{C}$ ); the inclination of strata varying from as much as $22^{\circ}$ (Figure $5 \mathrm{~B}$, arrow), to nearly horizontal. If the dip of Pinturas rocks was of tectonic origin, it is necessary to postulate a cumbersome tectonic history, and one in which numerous orogenic episodes took place in a relatively brief span of time. None of these hypothesized orogenies introduced appreciable alluvial debris, and none influenced, or bore any causal relation to, the extensive record of Pinturas intraformational erosion. Moreover, each successive tectonic phase must have decreased in intensity.

A depositional explanation for the inclination of Pinturas strata is more probable. The local "dip" of Pinturas rocks is invariably equivalent to the slope of the underlying surface, whether this surface is erosional topography on the Bahía Laura Group, on the Pinturas Formation, or on a depositional surface upon Pinturas strata (Figures 3, 4A, 5B, 9A). Because the slope of these surfaces must naturally decrease with progressive filling of either erosional or depositional topography, the upward decrease in inclination of Pinturas strata is explained.

Pyroclastic deposition in the Río Pinturas area was somewhat analogous to snowfalls; each more or less blanketing the erosional topography and with successive episodes spaced by much longer intervals of soil formation. Production of similar depositional dip is a 
well-known feature of pyroclastic sediment, one termed "mantle bedding" by Fisher \& Schminke (1984), who observed that ash-fall tephra can mantle surfaces with slopes of up to $30^{\circ}$. Slope wash allowed valley floors to fill more rapidly than valley margins, thus effecting the decrease in depositional dip seen up section, and affecting the expression and temporal relations of paleosols (see following section).

\section{Lower sequence}

The earliest recorded deposition of Pinturas rocks in the study area consists of a massive pink and brown bentonitic mudrock. This unit is best developed at Estancia El Carmen, where it fills a deep scour in the Bahía Laura Group, and it might be locally represented at Portezuelo Sumich Norte (Figure 6). It was succeeded by green and yellow pyroclastic mudrocks at the former locality and at Estancia Los Toldos. These sediments appear to have accumulated rather rapidly as their contained paleosols are very immature and show little horizonation. In all sections, except Cerro de los Monos and Loma de la Lluvia, the following 3-15 $\mathrm{m}$ is light gray pyroclastic mudrock upon which was developed the very mature paleosol zone. Collectively, these paleosols comprise a distinctive marker unit and indicate that pyroclastic production (or accumulation) was sporadic and that fluvial erosion was at a standstill.

At Portezuelo Sumich Norte, Estancia Ana Maria, and Estancia Los Toldos, the very mature paleosol zone is succeeded by: (1) green and yellow volcanic mudrocks; (2) pink and brown bentonitic mudrocks; and (3) massive gray volcanic mudrocks. The latter unit is indistinguishable from rocks of the upper sequence of the Pinturas Formation and is invariably truncated by the erosional unconformity separating the lower and middle sequences (Figure 6). At Estancia El Carmen, this unconformity instead truncates the very mature paleosol zone (Figure 5A). At Cerro de los Monos and Loma de la Lluvia, the lower sequence of the formation is made up of carbonaceous volcanic shales and mudrocks, followed by green and yellow volcanic mudrocks with very immature paleosols.

Paleotopographic relations indicate that the very mature paleosol zone was generally developed on topographic highs, the various volcanic mudrocks at intermediate levels, the carbonaceous units in low areas, and the pink and brown bentonitic mudrocks generally, but not invariably, in deep scours. These observations suggest a direct relationship, though not a very clear one, between episodes of pyroclastic production and those of intraformational erosion.

At most localities within the very mature paleosol zone, the constitutions and maturities of the paleosols change laterally downslope, along the paleotopography (paleocatena, Figure 10). This change is especially explicit at "el caldero" at Estancia Ana Maria, between the few exceptionally mature paleosols at relatively high topographic positions laterally to numerous paleosols of significant but lesser maturity found at lower topographic positions. The least mature of the paleosols in the upper part of the very mature paleosol zone separate the more mature paleosols from topographically low carbonaceous units. "Bedding" of Pinturas strata also conforms with underlying topographic perturbations, and was produced by textural and chemical zonation in the sediment during Miocene soil formation. Therefore the paleosols, like the deposits themselves, mirror topographically the surface on which they formed.

These relationships are not only interesting, they are necessary to equalize time between thick sediments with many immature paleosols lying in topographic depressions, and thinner deposits with fewer but more mature paleosols at more elevated topographic 


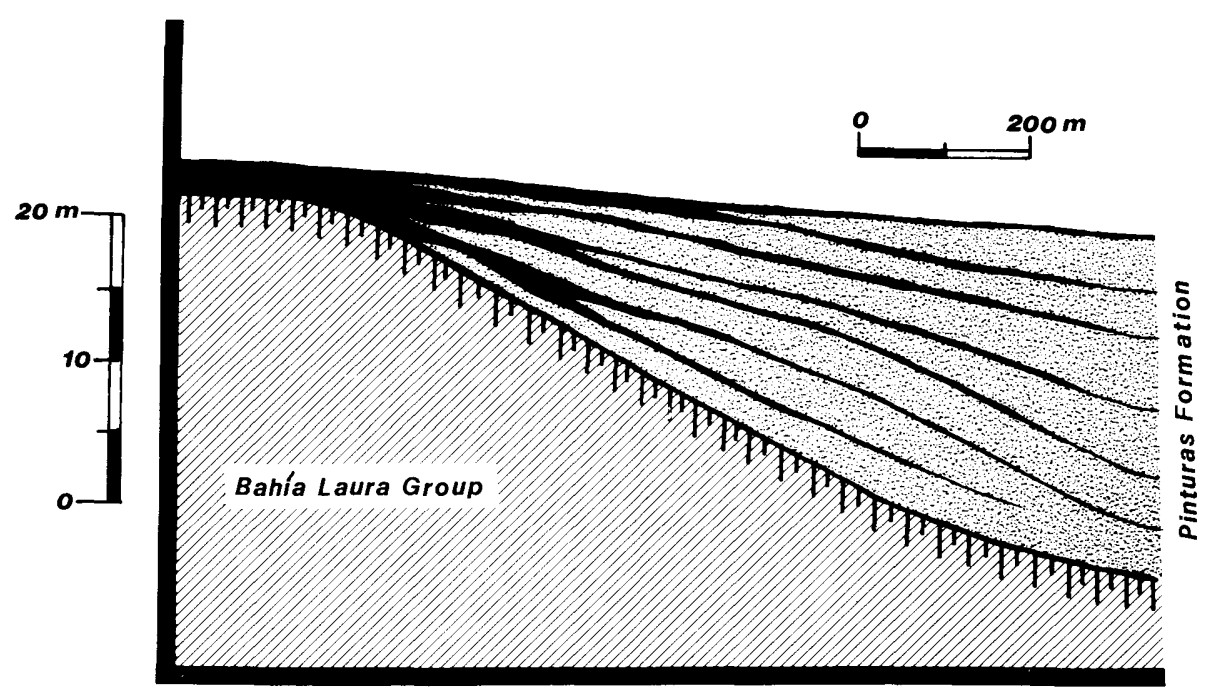

Figure 10. Diagram illustrating relationship of geologic time to sediment thicknesses across paleotopography, as determined by sections and lateral relations of paleosol maturities in the very mature paleosol zone of the lower sequence of the Pinturas Formation. Paleosols in the Pinturas Formation are depicted in black, with greater thickness denoting greater maturity (more time required to form). Note that, as with the alluvial pedofacies, thicker successions in areas of relatively rapid sediment accumulation contain more paleosols but of lesser maturity than in areas of slower sediment accumulation. Vertical lines at contact between the Jurassic Bahía Laura Group and the Pinturas Formation represent very mature pre-Pinturas paleosol. Relations are schematic and are based on exposures at "el caldero" at Estancia Ana Maria.

positions. The relation and integration of rock- and time-stratigraphic principles, majestically displayed by sediments and paleosols of the Pinturas Formation, is essentially that of a pyroclastic pedofacies, akin to the alluvial pedofacies documented by Bown \& Kraus (1987).

\section{Middle sequence}

One or two paleodune sandstones are presented in the middle sequence of the Pinturas Formation. These sandstones are composed of medium-fine sand, they have a general barchanoid geometry (e.g., Fryberger \& Dean, 1979), and they contain one or two large-scale inclined crossbeds, from 2-12 $\mathrm{m}$ thick. Measurements parallel to the inclination of the crossbeds yield consistent paleowind azimuths of $86-92^{\circ}$ (easterly). Their classification as barchanoid was arrived at by examination of the geometries of partly (Figure 5C) to nearly completely exhumed (Figure 7C) paleodunes. Specifically, they appear to be true barchans or, perhaps, barchanoid ridges. The paleodune sandstones are generally friable in their upper part and are moderately cemented with calcium carbonate in the lower few meters (Figures $7 \mathrm{~B}$ and $\mathrm{C}$ ). The calcite was probably mobilized by groundwater percolation following fill of interdune areas with pyroclastic mudrock. What appear to be Stokes surfaces (e.g., Fryberger et al., 1988) are well developed in some areas at Estancia Ana Maria, where they are represented by cemented paleodune sands that were truncated by penecontemporaneous Miocene deflation. Composition of the paleodune sand is largely non-volcanic, indicating access to sources other than the volcanic 
part of the Andean cordillera. As observed previously, paleodunes have now been recognized provisionally as a part of the coastal Santa Cruz Formation (Figures 9B and C; Larriestra et al., in press).

The dunes are entombed by green, yellow, and gray pyroclastic mudrocks containing paleosols, indicating that volcanicity alternated with the introduction of paleodune epiclastic sand, and that both were spaced by periods of little depositional activity. A significant erosional unconformity with a paleosol at its base separates the two dune deposits at Portezuelo Sumich Norte and Estancia Ana Maria. The older of the paleodune deposits lies on the major scour surface separating the lower and middle sequences of the Pinturas Formation. This relationship suggests, but does not prove, that both the erosion surface and the paleodunes might have a related origin, possibly structural elevation in the nearby Andes cordillera. This uplift would have lowered baselevels in the Pinturas region of the precordillera and might, at least for a time, have altered weather patterns and led to a somewhat drier regional climate. But the paleodunes might equally well indicate significant dryness only in source areas. Under this scenario, lowering of baselevels in the Pinturas area could also have been achieved by Atlantic eustasy, with or without any concomitant activity in the cordillera. Given the elevated position of the Pinturas lithotope in the precordillera, it was naturally subject to erosion, and it is unnecessary to postulate any relative elevation of cordillera nor depression of marine strandlines to explain erosion there in Pinturas time.

Thin volcanic pebble conglomerates that occur locally on Pinturas Stokes surfaces are similar to those seen by Ramos (1982) in the Ensenada Formation near Lago Cardiel. Ramos associated those conglomerates with elevation of the Andean cordillera; however, the thin, discontinuous, and volumetrically insignificant Pinturas psefites are unlikely to record appreciable Andean structural elevation. It is more likely that they simply record a time when temporarily increased local dryness allowed gradual headward erosion of degrading Pinturas streams to briefly achieve volcanic rock sources to the west.

\section{Upper sequence}

The upper sequence of the Pinturas Formation is a massive unit. The several immature paleosols within it, with dark gray, organic rich A horizons, attest to its having been deposited rather rapidly, though in several stages. The intraclastic breccia of volcanic mudrock which occurs in this sequence at some localities, especially proximal to confining paleotopography, probably was formed by colluvial erosion and earthflowing. This indicates that saturation of the newly-deposited sediment occurred at times, which is, in turn, suggestive of periodic significant rainfall. The variable contact relations of the upper sequence with the middle sequence of the Pinturas Formation (pronounced erosional unconformity at Estancia Ana Maria, Cerro de los Monos, and Estancia Los Toldos; minor, almost insignificant scouring at Estancia El Carmen; and paraconformity with immature paleosol at Portezuelo Sumich Norte) indicate that Portezuelo Sumich Norte and Estancia El Carmen were relatively distant from areas of stream incision at that time.

\section{Paleoenvironmental evidence of paleosols and fossils}

Paleosols in the Pinturas Formation indicate that the soil environment was normally moist. This is documented by moderate to pronounced epipedon development, appreciable clay and mineral translocation and some cutan development (even in very immature paleosols), 


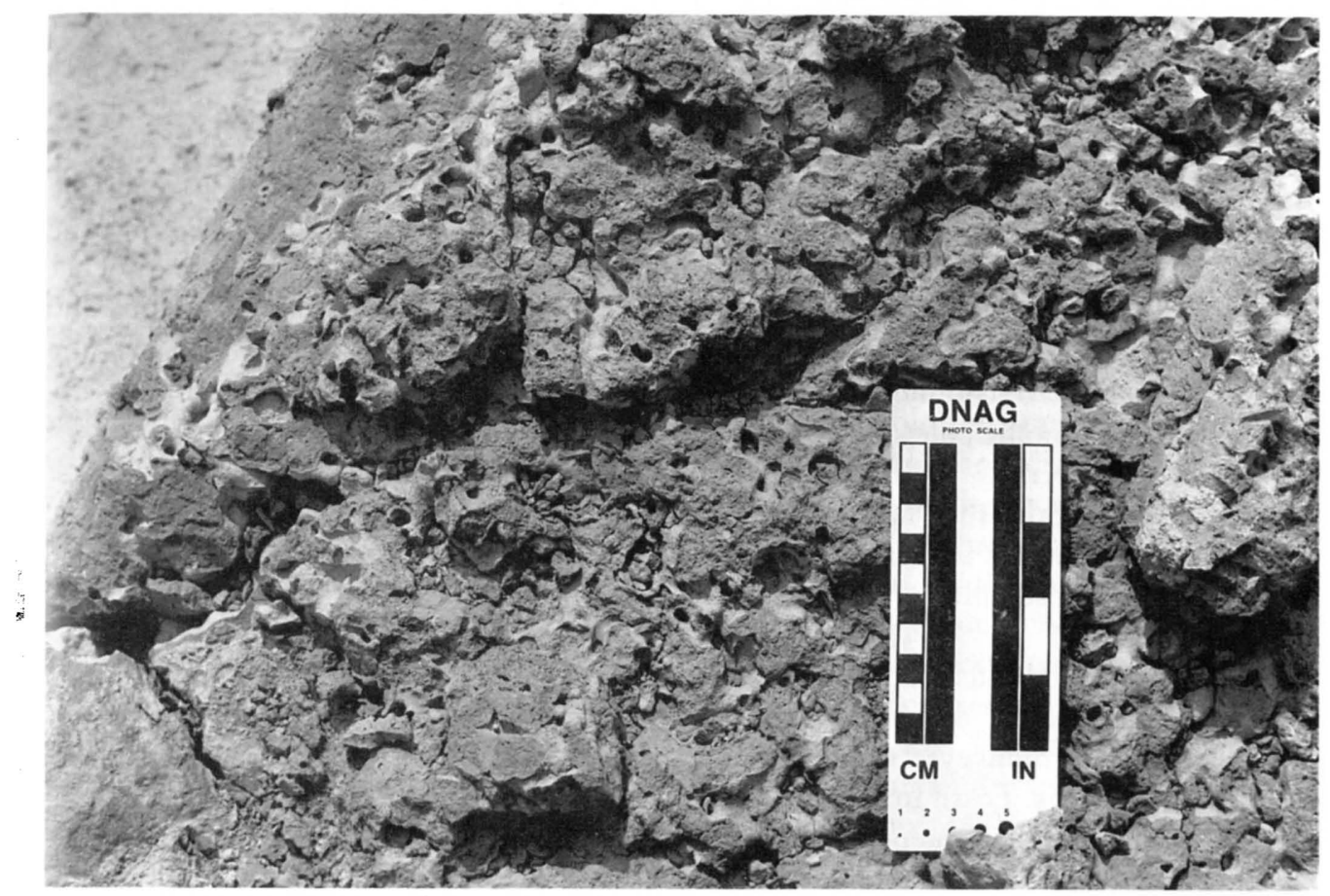

Figure 11. Fossil termite nest in very mature paleosol zone near base of lower sequence of Pinturas Formation, Arroyo Feo (see Bown \& Laza, in press). Note fine, compacted gray sediment lining galleries

ind absence of significant $\mathrm{CaCO}_{3}$ buildup. This interpretation is corroborated for the ower sequence by the existence of carbonaceous units.

The Pinturas paleosols show a tendency to decrease in general maturity through time. In exception is at the bases of the major scours, at nearly all of which relatively mature saleosols formed. That relationship suggests a general increase of volcanicity through time $r$, at the very least, an increase in pyroclastic material available from active volcanic sources. The net effect was a general increase in the Pinturas sediment accumulation rate. Because the depositional setting was a volcanic one, it seems that on a grand scale the accumulation cycle was one of: (1) sporadic deposition of pyroclastic material from distant sources, punctuated by soil formation (the intervals between deposition being in direct relation to paleosol maturity); (2) particularly violent or perhaps more proximal eruptions, followed by fires and deforestation; and (3) minor to considerable erosion, producing temporally modest to major intraformational unconformities and earth-flowage, depending on proximity to stream incision. Additional information on Pinturas depositional patterns is forthcoming from Pinturas holostrome restoration (see section below).

Trace fossils in the paleosols are both diverse and very abundant. In addition to those of rodents and ?dasypodids mentioned above, others record activity of many kinds of insects, including scarabeid beetles (for example, Frenguelli, 1938), termites (Figure 11), and several unattributed forms. Discovery of the fossil nest of a nasutitermitine termite in the 
very mature paleosol zone near the base of the Pinturas Fm. indicates the presence of areas of tropical forest (Bown \& Laza, in press). Nondescript bioturbation is practically ubiquitous in the lower and upper sequences of the formation. The paleodune sands in the middle sequence also locally contain abundant trace fossils-those of indeterminate colonial insects, rodents (Figure 8A), and an unknown invertebrate being the most common. Though the paleodunes seem to indicate an arid climate for the middle part of the Pinturas Formation, the abundance and variety of trace fossils in the middle sequence suggests that conditions were certainly not arid. The positions of both burrow tops and terminations in the paleodune sands indicate their formation contemporaneous with the dunes. Rhizoliths are common throughout the formation, but are best developed in the upper sola of the mollic paleosols. The rhizoliths and the poorly preserved, calcified boles of trees (see, e.g., Kraus, 1988) indicate that considerable vegetation, perhaps even forests, were at times typical of the Pinturas landscape. Carbonaceous shale deposits, such as occur in the lower sequence of the formation, cannot form in arid environments. Poorly preserved fish remains in those units in Arroyo Feo indicate ponding on the lower part of the lower Pinturas lithotope.

The vertebrate fauna is abundant, varied (see section below), and contains several elements suggestive of at least partly forested, adequately watered conditions. These include arboreal monkeys, caenolestid marsupials (some of which may have been arboreal), and frogs. Fossil mammals, including platyrrhine monkeys, occur in interdune deposits in the middle sequence of the Pinturas Formation at Estancia Ana Maria, Cerro de los Monos, and Loma de la Lluvia. These occurrences indicate that, if appreciable climatic drying did accompany dune formation, some forest-dwelling mammals (including monkeys) were either unaffected by it or quickly re-established themselves following dune formation. Vertebrate fossils, especially astrapotheres, hegetotheres, glyptodonts, and dasypodids, are common in the lower and middle parts of the upper sequence of the Pinturas Formation, but the primates are apparently absent. It is interesting that it is from this part of the formation that the calcified tree stumps occur. Perhaps the lack of primates reflects an inhospitable environment related to increased pyroclastic sediment accumulation rate, one great enough to have buried the stumps before their complete deterioration. Because correlation of this part of the Pinturas Formation with the platyrrhine-bearing Santa Cruz is insecure, it is equally likely that the boundary between the middle and upper sequences of the Pinturas Formation records their extinction in southern Argentina.

\section{Accumulation of vertebrate fossils}

The Pinturas Formation is quite rich in fossil mammals. Even though much additional work is necessary, it is appropriate here to outline what has been learned about the occurrences of the fossils. Composition of the mammal fauna is now known to vary both temporally and at different geographic sites in the same sequence. With two exceptions, neither the absolute numbers of fossils recovered nor the incidence of concentrations of them appear to be restricted to any particular sequences, or to units or levels within them that can be correlated between exposures. No vertebrate remains are known from the very mature paleosol sequence near the base of the formation, though this unit has been profoundly modified by insect and other invertebrate bioturbation (Bown \& Laza, in press). Vertebrates are exceedingly rare in the deposits of dune sand in the middle part of 
he formation, and also in the paleosols that developed on interdune deposits. Vertebrate ictivity, however, is abundantly represented in the paleodune deposits and elsewhere in he formation by hundreds of grouped burrows, probably representing rodent "villages". some of these burrows and their encasing deposits yield rare rodent skulls, teeth, and jaws. These, however, are but occasional finds and bear no relation to the major vertebrate oncentrations.

The fossils that occur in situ at the principal mammal localities in the Pinturas Formation appear to have accumulated either in paleosols or on the floors of paleovalley scours. This $s$ true of the several principal concentrations and the fewer random finds. Paleosol oncentrations of fossils in the lower third of the formation are generally associated with nore mature paleosols than are concentrations from the middle and upper thirds. Where it an be determined exactly which unit is yielding the fossils, they are derived from the upper art of the paleosol, generally from an organic carbon enriched A horizon. The remains are rincipally jaws with 2-4 teeth and isolated teeth (about $71 \%$, based on a sample of 296 pecimens). Bones, though mostly incomplete, are unabraded and apparently were not transported any significant distance. Tooth marks occur on about $14 \%$ of the long bones we have examined, indicating that some of the remains were scavenged prior to burial. Paleosol concentrations of fossil vertebrates occur in the local sections at Estancia Ana Maria, Cerro de Los Monos, Loma de la Lluvia, Estancia Los Toldos, and Estancia El Carmen. Preliminary work indicates that these concentrations are quite similar to the attritional paleosol assemblages described by Bown \& Kraus (1981).

Accumulations of fossils weathering from levels coincident with the floors of paleovalley scours is seen at Portezuelo Sumich Norte (where there is but one fossil locality), and at - pecific sites at Estancia Ana Maria and Estancia El Carmen. These sites are typified by abundant fossils with a lateral distribution limited to the boundaries of scour floors. At Portezuelo Sumich Norte, erosion along a tributary of Arroyo Feo has exposed two cross-sections of a single scour, more than $15 \mathrm{~m}$ deep and $30 \mathrm{~m}$ wide, on opposite sides of a badland ridge (Figure 9A). Fossils were found in profusion on flats at the base of the (then) unrecognized scour on both sides of the ridge; no specimens have yet been found farther laterally. A few centimeters of medium sand delimits and mantles the floor of the scour at Portezuelo Sumich Norte, but the fossil-producing scours are mud floored at both Estancia Ana Maria and Estancia El Carmen. The fossils are again relatively unabraded, suggesting that what little transport took place was probably slopewash from valley walls. As in the paleosol concentrations, the remains are dominated by jaw fragments and isolated teeth, and probably accumulated as a scavenged, attritional lag on the floor and sides of the valley.

Behrensmeyer (1988) has described two taphonomic modes for accumulation of attritional vertebrate assemblages in channels: channel-lag and channel-fill. The Pinturas paleovalley scour assemblages appear to be a special case of her channel-fill mode, one developed in the incised topography of a degrading alluvial regime (as opposed to abandoned channels of an aggrading regime), and one in which associated skeletal remains are rarely preserved.

\section{Correlation of Pinturas platyrrhine localities}

Fossil higher primates were found at eight principal localities in the Pinturas Formation. The primates were named by Fleagle et al. (1987) and Fleagle (1990). The sites and the 
fossil primates from them are as follows:

1. Portezuelo Sumich Norte (hereafter Sumich Norte, Carlocebus carmenensis, Carlocebus intermedius and Soriacebus ameghinorum);

2. Estancia Ana Maria (at Loma de las Ranas; hereafter Ana Maria, Carlocebus carmenensis and Soriacebus adrianae);

3. Cerro de los Monos (hereafter Monos, Carlocebus carmenensis, Soriacebus adrianae);

4. Loma de la Lluvia (hereafter Lluvia, Carlocebus carmenensis, Soriacebus adrianae);

5. Estancia los Toldos Sur (hereafter Toldos Sur, Carlocebus carmenensis);

6. Estancia El Carmen (two sites, hereafter Carmen lower and Carmen upper, Carlocebus carmenensis);

7. Estancia Los Toldos Norte (at Cauce Seca, hereafter Toldos Norte, Carlocebus carmenensis), and

8. Portezuelo Sumich Sur (hereafter Sumich Sur, Carlocebus carmenensis, Soriacebus adrianae).

It is desirable to relate these localities to one another stratigraphically to facilitate the examination of evolutionary sequences of the primates and associated faunas, as well as to provide a means for future separation of probable temporal and geographic influences on faunal composition for their correlation with those of the coastal Santa Cruz Formation. At the first six sites, enough section is preserved that their stratigraphic relations with respect to one another have been established with some confidence. The position of the seventh site, Toldos Norte, is problematical (for reasons given below); the eighth, Sumich Sur, is a small, isolated blowout, a few kilometers distant from the most proximal exposures that can be related directly to other localities.

Although the Pinturas Formation is relatively thin, as observed earlier, its depositional history is quite complicated owing to its position as a depocenter on the elevated margin of the Andean precordillera. Its proximity to sources of pyroclastic and aeolian debris provided ample and varied sediment at different times during Pinturas history, but its elevated position in the precordillera ensured considerable erosion during intervals of no deposition. At other times, when there was something of a balance between erosion and deposition, soils (now paleosols) formed; relatively mature paleosols representing rather longer intervals of sedimentation stasis than relatively immature paleosols (Bown \& Kraus, 1987). Exposures in the Río Pinturas valley are generally poor. Therefore, it is ironic that it is largely the complicated nature of the Pinturas depositional system that has facilitated correlation of the fossil localities within the formation. This correlation was established by relating the rather obvious unconformities, lithologic changes, and paleosols of varying maturity to one another in the widely scattered exposures. Intraformational correlation of fossil localities in the Pinturas Formation has allowed reconstruction of much of the original depositional sequences, and permits construction of a sedimentologically and temporally restored Pinturas section.

Due to the major erosional unconformity at the formation base, the generally thin sequences, and the disparate nature of Pinturas exposure, correlation of fossil localities within the Pinturas Formation hinges on a basic premise. This is that the $3-10 \mathrm{~m}$ thick zone of very mature paleosols, almost invariably found near the base of the formation where the base is exposed (Figure 6), formed penecontemporaneously at all of the sites where it occurs. The upper part of the very mature paleosol zone intertongues with carbonaceous volcanic mudrocks northwest of Sumich Norte. Elsewhere, the carbonaceous unit is a lithology that is also otherwise encountered only near the preserved base of the 
formation, and in areas in which the very mature paleosol zone is absent (for example, at Monos and Lluvia, Figure 6). Therefore, it appears that very mature paleosols were forming in some areas on the Pinturas lithotope at the same time that ponded or swampy conditions existed elsewhere. This ponding certainly indicates low local positions on the Pinturas lithotope.

The lowest known rocks of the Pinturas Formation occur at Estancia El Carmen, about $17 \mathrm{~km}$ south-southeast of Toldos Sur (Figure 2). The Estancia El Carmen exposure is the inly place at which an appreciable section exists beneath the very mature paleosol zone Figure 6). The stratigraphically lowest Pinturas primate specimens (Carmen lower) occur about $1.5 \mathrm{~m}$ beneath the base of the very mature paleosol zone at Estancia El Carmen, and bout $2.0 \mathrm{~m}$ above an ash-fall tuff dated at 16.6 \pm 1.5 . Ma (Bown et al., 1988b). A major rosional unconformity is present at the top of the very mature paleosol zone at Estancia El Carmen, and the floor of the paleovalley forming the unconformity is filled with a distinctive pink and brown volcanic mudrock. Another paleovalley (perhaps formed at the ame time) is filled with the same material at Sumich Norte (Figure 6), and occurs in upproximately the same stratigraphic position, cutting into the very mature paleosol zone. At Sumich Norte, however, the outcrop reveals the section lateral to the deepest part of the paleovalley - a section that is not preserved at Carmen (above the very mature paleosol zone and below the paleovalley fill). In this section, at the base of the pink and brown mudrock in the paleovalley scour, lies the Sumich Norte locality, The third oldest primate locality, Carmen upper, lies at a level equal to about the middle of the pink and brown paleovalley fill at Estancia El Carmen (Figure 6).

Correlation of three of the four remaining Pinturas primate localities is facilitated by the essentially tripartite nature of the formation; a lower sequence of pyroclastic mudrocks dominated by the very mature paleosols, a middle sequence of epiclastic dune sand and associated pyroclastic interdune deposits, and an upper sequence of massive gray ?roclastic mudrock. These units are recognizable throughout the Río Pinturas valley and ire separated from one another by major regional erosional unconformities. The localities Monos, Lluvia, and Ana Maria lie between the two unconformities - that at Monos identified by clear field relations, and that at Lluvia by inference; Lluvia is slightly above the lower unconformity but the exposure ends before the upper unconformity is encountered. Only a single deposit of paleodune sand is present at both Monos and Lluvia. This deposit lies directly on the lower unconformable surface and, at both sites, primate fossils occur directly above the dune sand. At Ana Maria there are two rather thick dune sand units and fossil primates occur near the base of a scour cut into the upper dune sand. These relations suggest that the Ana Maria site, though also within the middle part of the Pinturas Formation, is higher stratigraphically than either Monos or Lluvia. It would be at about the same level if it could be established that the solitary dune sands at Monos and Lluvia represent the upper sand at Ana Maria. This is unlikely because at Monos and Lluvia the solitary dune sand lies directly atop the lower unconformity.

The position of the Toldos Sur locality is enigmatic because the bed producing the primates has not been precisely located, and because the Toldos Sur section is regionally the most complicated. It appears that the primates come from one of two intervals, and these are separated by a major unconformity. The possibilities are: (1) any of the units above the lower, tabular, pink-brown pyroclastic mudrock (Figure 6) and beneath the first orerlying scour surface, and (2) somewhere above the latter scour surface, in the lenticular gray pyroclastic mudrock unit that is bounded by unconformities and lies in a deep scour 


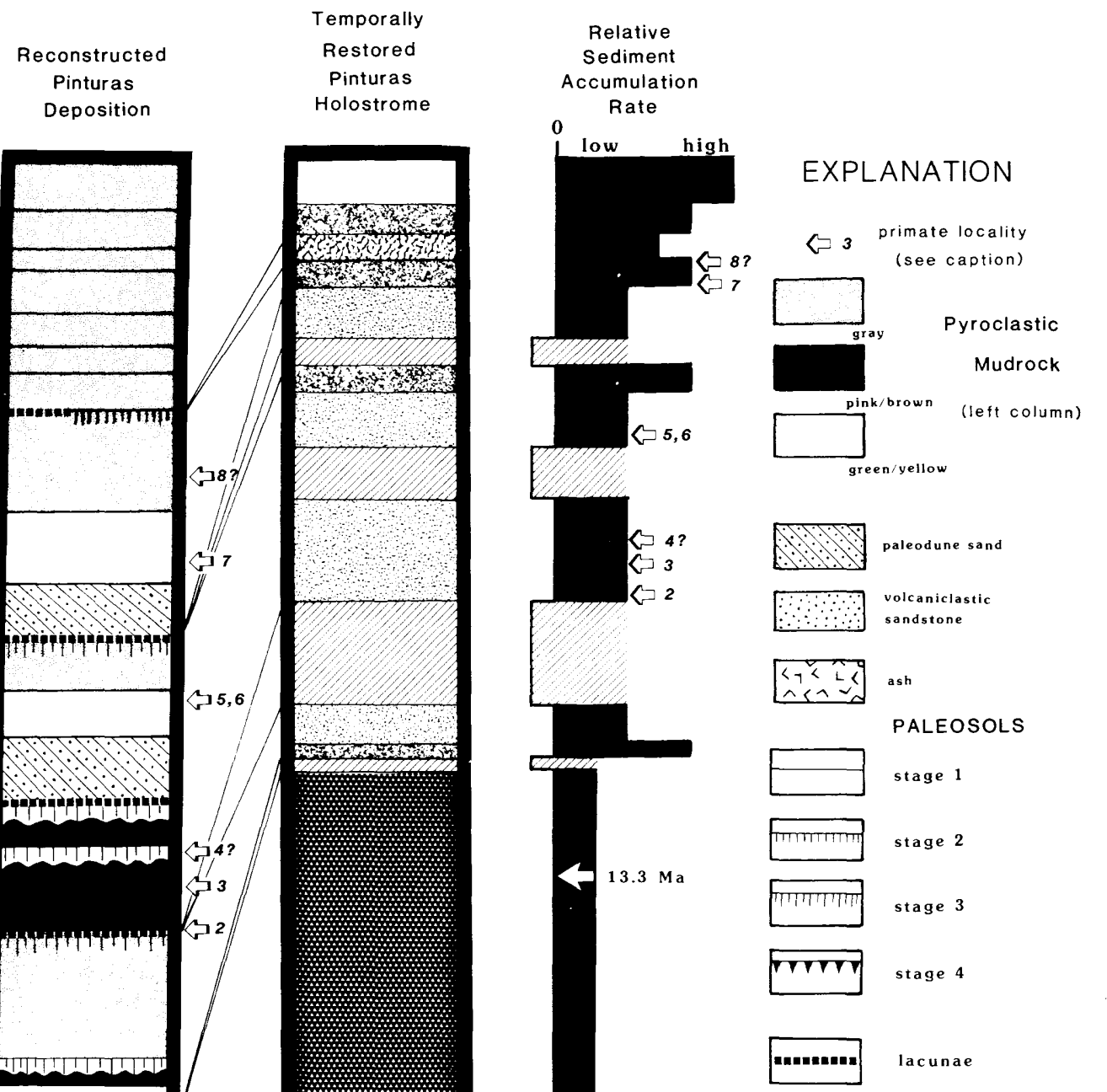

PALEOSOL (HIATAL) TIME

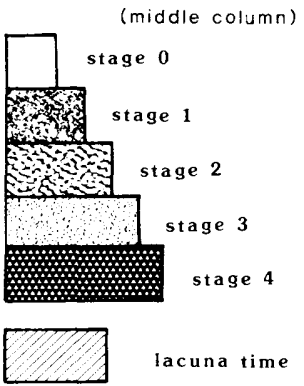

Figure 12. Reconstructed Pinturas Formation deposition (left column), temporally restored Pinturas holostrome (middle column), and relative sediment accumulation rates during Pinturas time as interpreted from paleosol maturities and radiometric dates (right column). Diagram depicts restored stratigraphic, sedimentologic, and temporal relations of fossil platyrrhine localities. Fossil localities: $1=$ Carmen lower; 2 Sumich Norte: $3=$ Carmen upper 4 ? $=$ Toldos Sur; $5=$ Monos: $6=$ Lluvia; $7=$ Ana Maria: 8 ? $=$ Sumich Sur (see Figure 6 for positions in measured sections). 
cutting into the first unit. The fossils definitely do not come from either of the two youngest scour fills at the top of the Toldos Sur column (Figure 6), both of which are developed only locally. There are no dune sand deposits at Toldos Sur, and the time interval for them is almost certainly contained in the lower unconformable surface. That this scour surface is a major one, representing all of time of the middle part of the Pinturas Formation is clear; it is underlain by the lower part of the Pinturas Formation and is overlain by the upper part. Therefore, the Toldos Sur primates are either relatively old, or much the youngest known :rom the formation. The former possibility is the more likely. Collections from all localities that occur positively in the upper sequence indicate that sequence introduces a largely new funa rich in glyptodonts and dasypodids and, though it is very rich in fossils of small nammals at some localities, none of these have yet yielded primates. If from the lower of the two optional stratigraphic positions, Toldos Sur is intermediate in position between Carmen upper and Monos/Lluvia.

Based on the above correlations, the stratigraphic arrangement of fossil primate-bearing lincalities in the Río Pinturas valley (from oldest to youngest) is therefore: (1) Carmen lower; (2) Sumich Norte; (3) Carmen upper; (4?) Toldos Sur; (5) Monos and Lluvia approximately equal position); (6?) Sumich Sur and Toldos Norte (Cauce Seca); and (7) Ina Maria. The primate appearances therefore follow one another temporally, thus: Carlocebus carmenensis, C. intermedius and Soriacebus ameghinorum, Soriacebus adrianae.

Sumich Sur is developed on a sandy gray volcanic mudrock indistinguishable from that between paleodune deposits in the middle sequence of the Pinturas Formation at Estancia Ana Maria. Toldos Norte (Cauce Seca) lies beneath the unconformity separating the middle and upper sequences at Toldos Sur and above a stratified deposit of paleodune and, placing this locality in the middle or upper part of the middle sequence of the Pinturas Formation.

\section{Reconstruction of the Pinturas section and restoration of the Pinturas holostrome}

In his classic work on time-stratigraphy, Wheeler (1958) introduced the possibility of using restored sections in stratigraphic correlation. Elaborating concepts developed partly by Blackwelder (1909), Wheeler (1958: 1050) conceived of objective time-stratigraphic units as "all three-dimensional entities (material, non-material, or combinations of both) which ... are defined" [by] "two lateral space dimensions and a vertical time dimension." These entities "must delineate all interpreted deposition...non-deposition, postdepositional erosion removal, or whatever combination of these may be useful in the interpretation and visualization of geologic history." This concept was embodied in his new term, the holostrome; i.e., the complete restored deposition, including preserved strata and lacunae. The "objective frameworks of reference" for the holostrome are -equences-assemblages "of strata exhibiting similar responses to similar tectonic environments over wide areas, separated by objective horizons without specific time ignificance" (Wheeler, 1958: 1050; see also Sloss et al., 1949). Though Wheeler advanced these concepts through his studies of transgressive and regressive sequences, they have (as Wheeler recognized) application to the correlation and elucidation of sequences of any urigin.

In this work, the Pinturas Formation has been separated into three such sequences (the lower, middle, and upper), with the "objective horizons" being the major intraformational 
erosional unconformities. The Pinturas Formation contains numerous paleosols, some relationships of which to time- and rock-stratigraphy were outlined by Retallack (1983a, $1983 b$, 1984), and by Kraus \& Bown (1986). In Wheeler's terminology, a paleosol represents a hiatus, i.e., a time interval represented by no significant deposition. The scours are erosional vacuities, or the non-material parts of a holostrome formerly represented by deposits. The material removed by scouring, including sediment and whatever paleosols were formed on it, comprises a lacuna, i.e., a time interval of both erosion and non-deposition.

To restore the Pinturas holostrome, it was necessary: (1) to reconstruct a composite Pinturas rock section based on all known depositional units placed in their correct relative stratigraphic order; (2) to provide some sort of empirical basis for measuring relative time contained in erosional intervals (lacunae); and (3) to provide an empirical basis for evaluation of relative time contained in the paleosols (hiatuses). A composite reconstructed Pinturas section was made by simple correlation of paleosols, unconformities, and marker beds between the six sections illustrated in Figure 6, and interpolating units present in some of these sections, but absent in others due to erosion. Some of the details of this reconstruction were presented at the end of the preceding section, and the reconstructed section is depicted in the left column of Figure 12. The temporal significance of erosional vacuities was assessed by tracing the scours laterally to their margins and interpolating values for paleosols in the preserved (unremoved) rock. For the paleosols (hiatuses), a relative maturity index $(1=$ very immature, $2=$ immature, $3=$ mature, and $4=$ very mature) was formulated on the basis of the combined A and B horizon thickness, following the procedure established by Bown \& Kraus (1987). In determining relative time, raw parent material was accorded a value of zero (the time of actual deposition of individual units being practically instantaneous geologically), very immature paleosols a value of 1 , immature paleosols a value of 2 , mature paleosols a value of 4 , and very mature paleosols a value of 8 . The latter high values reflect the general decrease in maturation rate through time (Bown \& Kraus, 1987).

The restored Pinturas holostrome is shown in the second column of Figure 12. This column depicts the various depositional units, paleosols, and degradational intervals corrected for the relative amount of total Pinturas time represented by each. The bulk of this time (about two-thirds) is occupied by the lower sequence of the formation, in particular, by the very mature paleosol zone (about $45 \%$ ). Because paleosol maturity is a good index of sediment accumulation rate (Bown, 1985; Kraus \& Bown, 1986; Bown \& Kraus, 1987), relative values for varying sediment accumulation rates through time can be derived directly from the holostrome. This information is depicted in column 3 of Figure 12 , in which unrestored lucunae are shown as less than 0 net sediment accumulation rate, and rates increase in an indirect relation to paleosol maturity. That is, uneroded immature paleosols indicate that there was relatively little time for the soils to mature before deposition of more sediment (sediment accumulation rate was relatively rapid), and more mature paleosols indicate more time available for soil maturation before the next depositional episode (sediment accumulation rate was relatively slow).

From column 3 of Figure 12, it is seen that the sediment accumulation rate for Pinturas deposition fluctuated considerably but tended to increase during the time represented by the middle and upper sequences of the formation. Also obvious is that the most significant increases in accumulation rate were almost invariably followed by important intervals of regional erosion. In an alluvial setting, this phenomenon might be interpreted to reflect 
creles of structural elevation in source areas and/or concomitant sea level fluctuations. However, because the Pinturas depositional setting was pyroclastic aeolian, and stream a tion was largely confined to erosion, it would seem more likely that the act of deposition s:mehow directly influenced the subsequent erosion. It is suggested that increased p. roclastic production resulted in fires and deforestation, enhancing erosion of Pinturas sediment. Although it is impossible to substantiate this interpretation by more direct nicans, it is clear that no significant regional (or even local) erosion took place during the loig interval of formation of the very mature paleosol zone. Therefore, intervals of erosion in the elevated precordillera were not instigated simply by appreciable decreases in p roclastic production.

The advantages of holostrome restoration should be obvious. In spite of the great pinsibility of introducing errors in time resolution, if the estimates are even reasonably clise to actual proportions, the restored holostrome is a far more accurate depiction of the riative organization of geological and biological events in time. The information obtained can be used to considerable advantage in relating sedimentary and tectonic events, and rates of sediment accumulation and mammal evolution.

\section{Age and correlation of Pinturas Formation}

As outlined in the introduction, some earlier workers have suggested that the Pinturas rrtebrate fauna is earliest Santacrucian in age, and might even include some forms more typical of the late Oligocene Colhúehuapian. Others averred that, although the Pinturas fauna is certainly Santacrucian, its precise placement within that land-mammal age is uncertain. It has also been believed likely that the Pinturas Formation contains time equivalents of both the marine Patagonian Formation and the lower part of the type Santa Cruz Formation. Unfortunately, and in spite of the quite large collections of Pinturas nammals recovered in the last several years, their preparation and identification for study has not kept pace with the need for their use in correlation, both with faunas of the type $S$ intacrucian and those of the younger Friasian. Moreover, recognition of distinct Pinturas futunas bounded by significant intraformational unconformities in the Pinturas section offers the question: from exactly which Pinturas sequences did the original collections come?

Based on new radiometric dates from the type area, Marshall et al. (1986) believed Santacrucian time to comprise that interval between about 18.0 and $15.0 \mathrm{Ma}$, thus commencing well after the start of the Miocene (23.5 Ma; Berggren et al., 1985). Bown et al. (1988b) published a data of $16 \cdot 6 \pm 1.5 \mathrm{Ma}$ for rocks near the base of the Pinturas section at Estancia El Carmen (Figure 6). A second Pinturas date (13.3 $\pm 3.3 \mathrm{Ma}$ ) was recently obtained from a tuff in the carbonaceous volcanic mudrocks at Loma de la Lluvia. Similar carbonaceous volcanic mudrocks (lacking datable tuffs) appear to correlate with the uppermost part of the very mature paleosol zone in Arroyo Feo. Therefore, if all of the carbonaceous mudrocks in the Pinturas Formation are the same age and both radiometric dates are reliable, the very mature paleosol zone required about $3 \mathrm{~m} . \mathrm{y}$. to form, the lower sequence of the Pinturas Formation ranges in age from latest early Santacrucian to at least later Friasian time, and most of the Pinturas primates (in fact, most of the fauna) is younger than $13.3 \mathrm{Ma}$. By a wide margin, this would be the youngest age ever proposed for the Pinturas faunas. Keeping in mind that the Pinturas fauna has not been studied comprehensively, and that its composition changes markedly up section (especially 
between the middle and upper parts of the sequence), more detailed correlation must await a major faunal analysis. It may be significant that the oldest span of lower Pinturas radiometric dates (accommodating possible error) is $18 \cdot 1-16.6 \mathrm{Ma}$. This range includes almost all of early Santacrucian time and is therefore generally compatible with previous Pinturas age assessments from Pascual et al. (1965) on. The youngest span (15.1-10.0 Ma) is basically Friasian and Chasicoan (of Marshall et al., 1986), or middle Santacrucian through Friasian (of Patterson \& Pascual, 1972).

Bown et al. (1988b) published a date of $15 \cdot 8 \pm 2 \cdot 5 \mathrm{Ma}$ for an ash occurring $20 \mathrm{~m}$ above Trelew beds yielding Colhúehuapian mammals near Gaiman, Chubut Province. A second dating of this ash has provided a similar age of $16 \cdot 6 \pm 0 \cdot 8 \mathrm{Ma}$. Both dates suggest that the Gaiman ash is the same age as, or slightly younger than, the lower part of the lower sequence of the Pinturas Formation at Estancia El Carmen. Additional fieldwork in 1989 on the Gaiman tuff indicates conclusively that it lies in the base of the nearshore marine Gaiman Formation (Mendia \& Bayarsky, 1981), and not in the upper part of the Trelew Member of the Sarmiento Formation. The Gaiman Formation date corroborates the impressions of several workers that some of the Pinturas and Santa Cruz mammal faunas correlate with marine rocks of the Patagonian series.

\section{Resumen}

La Formación Pinturas es un depósito sedimentario de origén piroclástico y epiclástico eólico de edad Mioceña inferior, que yace sobre rocas Jurásicas y aflora en la región extrandina del noroeste de la provincia de Santa Cruz, República Argentina. La historia del desarrollo de la Formación Pinturas fue significativamente afectada por el garadual, aunque esporádico, amoldamiento y lento relleno de la paleotopografia por estos sedimentos. Los ciclos deposicionales de Pinturas consistieron en: (1) una menor deposición eólica seguida por formación de suelos, y (2) una mayor deposición eólica seguida por intervalos de erosión regional. La erosión fluvial parece haber sido casi totalmente confinada a la erosión intraformacional, por lo que dos importantes discordancias erosivas dividen la Formación Pinturas en tres secuencias, a saber: la secuencia inferior dominada por pelitas piroclásticas sobre las cuales se formaron paleosuelos muy maduros, probablemente mólicos; la secuencia media compuesta mayormente por psamitas epiclásticas ocurriendo como paleodunas barjanoides; y la secuencia superior caracterizada por pelitas piroclásticas masivas con pobre estratificación. Las lacunae de Pinturas fueron reconstruidas sobre la base de los estratos preservados localmente, y un nuevo método de reconstrucción del holostromo usando la relativa madurez de los paleosuelos desarrollados durante la sedimentación de Pinturas, para establecer una mayor precisión temporal de la sucesión de los eventos. Esto permitió establecer que: (1) la tasa de sedimentación de la Formacion Pinturas se incrementó con el tiempo; (2) que los mayores intervalos erosivos son correlacionados directamente con la mayor proporción de sedimentación piroclástica; y (3) que la aparición de los Platyrrinos de Pinturas sucedió en el siguiente orden: Carlocebus carmenensis, C. intermedius y Soriacebus ameghinorum, y Soriacebus adrianae.

Los paleosuelos de Pinturas parecen haber sido formados bajo condiciones húmedas definidas, y tanto las variedades maduras como las inmaduras produjeron una cantidad importante de icnofósiles. Estos incluyen cuevas y nidos de escarabéidos, termitas y al menos dos tipos diferentes de crotovinas asignadas a roedores coloniales, junto con raices y 
roncos calcificados. Las condiciones climáticas parecerian haber sido más secas durante la leposición de las dunas en el comienzo de los episodios finales de la sedimentación de la Formación Pinturas; o estos depósitos podrian reflejar condiciones más secas en el área vrocedencia o simplemente haber invadido áreas elevadas con cubierta boscosa. Las : bundantes acumulaciones de mamiferos fósiles con algún signo de transporte fueron reconocidas en la parte superior de los paleosuelos y en los pisos de los paleovalles producto de la erosión. Las dataciones radiométricas indican que los mamiferos fósiles (incluidos los primates platirrinos) que se encuentran en la parte inferior y media de la formación, varian in edades desde 16.6 hasta 13.3 Ma (desde edad mamalifera Santacrucense hasta, muy probablemente, Friasense). Esta rango de edades es algo más joven que las estimadas previamente y sugiere que las faunas de Pinturas se correlacionen ampliamente con aquellas pertenecientes a la Formación Santa Cruz, como asi también con las asignadas al tipo Friasense y con aquellas que se encuentran en la base de los estratos marinos de la Formación Gaiman que aflora en el valle inferior del Río Chubut.

\section{Acknowledgements}

We are grateful to J. G. Fleagle and M. J. Kraus for reviews of earlier drafts of this manuscript, and to V. Escribano, J. G. Fleagle, and D. W. Powers for discussion. J. F. Bonaparte and M. F. Soria of the Museo Argentino de Ciencias Naturales (Buenos Aires) aided with many matters material to our investigations, and we thank A. Albino, G. Buckley, G. C. Conroy, S. Cornero, C. Dubois, and E. Schloeder for their able field assistance. Radiometric age determinations were supplied by J. D. Obradovich, C. W. Naeser, and K. Tabbutt. The expeditions were supported by grants to J. G. Fleagle from the L. S. B. Leakey Foundation, The National Geographic Society, and N.S.F. (grant B.NS8606796). We are especially grateful to J. G. Fleagle and J. F. Bonaparte for the invitation to participate in their joint investigation.

\section{References}

Ameghino, F. (1889). Contribución al conocimiento de los mamíferos fósiles de la República Argentina, obra escrita bajo los auspicios de la Academia Nacional de Ciencias de la República Argentina para presentarla a la Exposición Universal de Paris de 1889. Actas Acad. Cienc. Córdoba VI, 1-1027.

Ameghino, F. (1900-1902). L'age des formations sedimentaires de Patagonie. Anals. Soc. Cienc. Argentinas 54, $161-180$.

Ameghino, F. (1906). Les formations sedimentaires du Crétacé supérieur et du Tertiaire de Patagonie avec un paralèlle entre leurs faunes et celles de l'ancienne continent. Anals. Mus. Nac. Buenos Aires 15 (ser. 3a, 8), l-j68.

Bavarsky, A. (1982). Estudio sedimentológico de muestras provenientes de la formación Santa Cruz, Hojas 53c, I.aguna Olin, y j2c, Bajo Caracoles, Provincia de Santa Cruz. Serv. Geol. Nac., Buenos Aires, mimeographed eport.

Behrensmeyer, A. K. (1988). Vertebrate preservation in fluvial channels. Palaeogeogr., Palaeoclimatol., Palaeoecol. $63,183-199$.

Berggren, W. A., Flynn, J. J. \& Kent, D. V. (1985). Jurassic to Paleogene: Part 2, Paleogene geochronology and chronostratigraphy. In (N. J. Snelling, Ed.) The Chronology of the Geologic Record; Geol. Soc. Am. Mem., 10, $1+1-195$.

Blackwelder, E. (1909). The valuation of unconformities. J. Geol. 17, 289-299.

Buwn, T. M. (1985). Maturation sequences in lower Eocene alluvial paleosols, Willwood Formation. In (R. M. Flores \& M. Harvey, Eds), Field Guidebook to Modern and Ancient Flucial Systems in the Linited States, pp. 20-26. Third Internat. Fluv. Sed. Conf. Proc.

Bown, T. M. \& Kraus, M. J. (1981). Vertebrate fossil-bearing paleosol units (Willwood Formation, lower Eocene, northwest Wyoming, L.S.A.): implications for taphonomy, biostratigraphy, and assemblage analysis. Palaeogeogr., Palaeoclimatol., Palaeoecol. 34, 31-j6. 
Bown, T. M. \& Kraus, M. J. (1987). Integration of channel and floodplain suites, I. Developmental sequence and lateral relations of alluvial paleosols. J. Sed. Petrol. 57, 587-601.

Bown, T. M. \& Laza, J. (in press). A fossil nest of a Miocene termite from Southern Patagonia, Argentina, and the oldest record of the termites from South America. Ichnos.

Bown, T. M., Larriestra, C. ‥ \& Powers, D. W. (1988a). Análisis paleoambiental de la formación Pinturas (Mioceño Inferior), Provincia de Santa Cruz. Segunda Reun. Argentina Sed. Actas 1. 31-35.

Bown, T. M., Larriestra, C. N., Powers, D. W., Naeser, C. W. \& Tabhutt, K. (1988b). New information on age, correlation, and paleoenvironments of fossil platyrrhine sites in Argentina. J. Vert. Paleont. 8, 9A.

Castellanos, A. (1937). Ameghino y la antiguedad del hombre sudamericano. Conf. Asoc. Cult. (Rosario), Cic. Caract. Gen. 2, 47-192.

de Barrio, R. E., Scillato Yané, G. \& Bond, M. (1984). La formación Santa Cruz en el borde occidental del macizo del Deseado (Provincia de Santa Cruz) y su contenido palcontológico. Actas Noz. Congr. Cieol. Argentino (S. C. de Bariloche, 1984) IV, 539-556.

Di Persia, C. (1959). Levantamiento geológico de la parte norte de la provincia de Santa Cruz al sur del Rio Deseado. 6-campana, Yac. Petrol. Fisc., Buenos Aires, (mimeographed).

Fisher, R. V'., and Schminke, H.-L. (1984). Pyroclastic Rocks. Berlin: Springer-Verlag.

Fleagle, J. G. (1990). New fossil platyrrhines from the Pinturas Formation, southern Argentina. J. hum. Ezol. 19, $61-85$.

Fleagle, J. G., Powers, D. W., Conroy, G. C. \& Watters, J. P. (1987). New fossil platyrrhines from Santa Cruz Province, Argentina. Folia primatol. 48, $6 \bar{j}-\bar{i} 7$.

Frenguelli, J. (1931). Nomenclatura estratigráfica patagónica. Ans. Soc. Cienc. Santa Fe 3, 1-115.

Frenguelli, J. (1938). Bolas de escarabéidos y nidos de vespidos fósiles. Soc. Argentino Cienc. Vatur. Rer. 12, 348-351.

Fryberger, S. G. \& Dean, G. (1979). Dune forms and wind regime. In (E. D. McKee, Ed.) Cilobal Sand Seas, pp. 137-169. U.S. Geol. Surv. Prof. Paper 1052.

Fryberger, S. G., Schenk, C. J. \& Krystinik, L. F. (1988). Stokes surfaces and the effects of near-surface groundwater-table on aeolian deposition. Sedimentol. 35, 21-41.

Kraus, M. J. (1988). Nodular remains of early Tertiary forests. Bighorn Basin, Wyoming. J. Sed. Petrol. 58, 888-893.

Kraus, M. J. \& Bown, T. M. (1986). Paleosols and time resolution in alluvial stratigraphy. In (P. V. Wright, Ed.) Paleosols: Their Recognition and Interpretation, pp. 180-207. London: Blackwell.

Larriestra, C. N., Escribano, V.\& Bown, T. M. (in press). Eolianitas de la formación Santa Cruz en la localidad de Monte Observatorio, Provincia de Santa Cruz. Asoc. Geol. Argentina Rez:

Marshall, L. G. (1976). Fossil localities for Santacrucian (early Miocene) mammals, Santa Cruz Province, southern Patagonia, Argentina. J. Paleontol. 50, $1129-1142$.

Marshall, L. G., Cifelli, R. L., Drake, R. E. \& Curtis, G. H. (1986). Geochronology of type Santacrucian (middle Tertiary) land mammal age, Patagonia, Argentina. J. Geol. 94, 449-457.

Marshall, L. G., Hoffstetter, R. \& Pascual, R. (1983). Mammals and stratigraphy: geochronology of the continental mammal-bearing Tertiary of South America. Palaeovertebrata, Mem. Extraord. 1-93.

Narshall, L. G., Pascual, R., Curtis, G. H. \& Drake, R. E. (1977). South American geochronology: radiometric time scale for middle to late Tertiary mammal-bearing horizons in Patagonia. Science 195, 132.j-1328.

Mendia, J. F. \& Bayarsky, A. (1981). Estratigráfia del Terciario en el valle inferior del Río Chubut. IIII Congr. Geol. Argentino, San Luis, Actas 3, 593-606.

Nullo, F. E., Proserpio, C. A. \& Ramos, V. A. (1978). Estratigráfia y tectonica de la vertiente este del Hielo Patagónico, Argentina y Chile. III Congr. Geol. Argentino, Actas 1, 45j-470.

Pascual, R., Ortega Hinojosa, E.. Gondar, D. \& Tonni. E. (1965). Las edades del Cenozoico mamalífero de la Argentina, con especial atención a aquellas del territorio bonaerense. Anls. comis. Iniest. Cienc., Buenos Aires $\mathbf{6}$, $165-193$.

Pascual, R. \& Odreman Rivas, O. E. (1971). Evolución de las comunidades de los vertebrados del Terciario argentino. Los aspectos paleozoogeográficos y paleoclimáticos relacionados. Ameghiniana 8, 372-412.

Patterson, B. \& Pascual, R. (1972). The fossil mammal fauna of South America; (In A. Keast. F. C. Erk \& B. Glass, Eds), Euolution, .Hammals, and Southern Continents. pp. 247-309. Albany: State University of New York Press.

Ramos, V. A. (1982). Geología de la region del Lago Cardiel, Provincia de Santa Cruz. Asec. Geol. Argentina Rev. 37, 23-49.

Retallack, G. J. (1983a). Late Eocene and Oligocene paleosols from Badlands National Park, South Dakota. Geol. Soc. Am. Spec. Pap. 193, 82 pp.

Retallack, G.J. (1983b). A paleopedological approach to the interpretation of terrestrial sedimentary rocks: the mid-Tertiary fossil soils of Badlands National Park, South Dakota. Geol. Soc. Am. Bull. 94, 823-840.

Retallack, G. J. (1984). Completeness of the rock and fossil record: some estimates using fossil soils. Paleobiol. 10, 59-78.

Roellig, F. (1982). Estudio por difractometría de rayos X de muestras arcillosas provenientes de las Hojas $53 \mathrm{c}$, Laguna Olín, y 52c, Bajo Caracoles, Provincia de Santa Cru\%. Serr. Cieol. Nac., Buenos Aires: mimeographed report. 
Sarage, D. E. \& Russcll, D. E. (1983). Mammalian Pateofaunas of the World. London: Addison-Wesles:

Sloss, L. L., Krumbein, F. C. \& Dapples, E. C. (1949). Integrated facies analysis. Geol. Soc. Am. Mem. 39, $91-124$. Wheeler, H. E. (1958). Time-stratigraphy. Am. Assoc. Petrol. Geol. Bull. 42, 1047-1063.

Wood, A. E. \& Patterson, B. (1959). Rodents of the Deseadan Oligocene of Patagonia and the beginnings of South American rodent evolution. Bull. .Mus. Comp. Zool. 120, 281-428. 